Published in final edited form as:

J Med Chem. 2016 September 08; 59(17): 7877-7887. doi:10.1021/acs.jmedchem.6b00640.

\title{
Small Antimicrobial Agents Based on Acylated Reduced Amide Scaffold
}

\author{
Peng Teng ${ }^{\dagger, \perp}$, Da Huo ${ }^{\ddagger, \perp}$, Alekhya Nimmagadda ${ }^{\dagger, \perp}$, Jianfeng Wu ${ }^{\S}$, Fengyu She ${ }^{\dagger}, \mathrm{Ma} \mathrm{Su}^{\dagger}$, \\ Xiaoyang Lin", Jiyu Yan", Annie $\mathrm{Cao}^{\dagger}$, Chuanwu Xi ${ }^{*}$, , Yong Hu${ }^{*} \neq$, and Jianfeng Cai ${ }^{*}, \ddagger$ \\ tDepartment of Chemistry, University of South Florida, 4202 E. Fowler Avenue, Tampa, Florida \\ 33620, United States \\ ‡Department of Biomedical Engineering, College of Engineering and Applied Science, Nanjing \\ University, 22 Hankou Road, Nanjing, Jiangsu 210093, P. R. China \\ $\S$ Department of Environmental Health Sciences, University of Michigan School of Public Health, \\ 1415 Washington Heights, Ann Arbor, Michigan 48109, United States \\ "College of Pharmacy, University of South Florida, 4202 E. Fowler Avenue, Tampa, Florida 33620, \\ United States
}

\section{Abstract}

Prevalence of drug-resistant bacteria has emerged to be one of the greatest threats in the 21st century. Herein, we report the development of a series of small molecular antibacterial agents that are based on the acylated reduced amide scaffold. These molecules display good potency against a panel of multidrug-resistant Gram-positive and Gram-negative bacterial strains. Meanwhile, they also effectively inhibit the biofilm formation. Mechanistic studies suggest that these compounds kill bacteria by compromising bacterial membranes, a mechanism analogous to that of hostdefense peptides (HDPs). The mechanism is further supported by the fact that the lead compounds do not induce resistance in MRSA bacteria even after 14 passages. Lastly, we also demonstrate that these molecules have therapeutic potential by preventing inflammation caused by MRSA induced pneumonia in a rat model. This class of compounds could lead to an appealing class of antibiotic agents combating drug-resistant bacterial strains.

\section{Graphical abstract}

\footnotetext{
*Corresponding Authors: C.X.: cxi@umich.edu; phone, 734-615-7594; Y.H.: hvyong@ @ju.edu.cn; phone, 86-25-83594668; J.C.: jianfengcai@usf.edu; phone, 813-974-9506; fax, 813-974-3203.

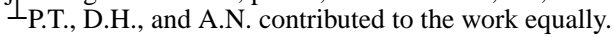

Supporting Information

The Supporting Information is available free of charge on the ACS Publications website at DOI: 10.1021/acs.jmedchem.6b00640.

${ }^{1}$ H NMR spectra, HPLC traces, and HR-MS results of compounds 1-16 and experimental details (PDF) Molecular formula strings and some data (CSV)

Notes

The authors declare no competing financial interest.
} 


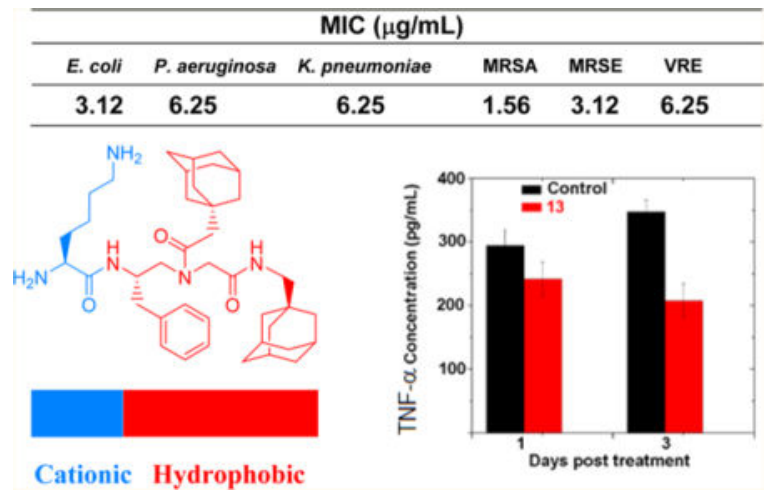

\section{INTRODUCTION}

Antibiotic resistance in bacteria is one of the most critical concerns faced in global public health. ${ }^{1}$ Notorious multidrug-resistant strains, including Gram-positive bacteria methicillinresistant Staphylococcus epidermidis (MRSE), methicillin-resistant Staphylococcus aureus (MRSA), vancomycin-resistant Enterococci faecalis (VRE), and Gram-negative bacteria Escherichia coli (E. coli), Klebsiella pneumoniae, Pseudomonas aeruginosa, have emerged to be the major cause of hospital and community-acquired infections. ${ }^{2,3}$ As conventional antibiotics are observed to elicit escalating resistance, significant efforts have been extended to the investigation of host-defense peptides (HDPs) and their derivatives as alternative therapeutic strategies. ${ }^{4-6}$ Natural antimicrobial peptides, also known as HDPs, have attracted substantial interest in the past decade, and a few of them, such as PMX30063 and LTX109, are currently in clinical trials. ${ }^{4-7}$ HDPs are produced by living organisms as the first line of defense against a wide variety of infections. ${ }^{5}$ Unlike conventional antibiotics that target specific membrane or intracellular components of bacteria, HDPs preferentially interact with bacterial membranes and lead to the destruction of membranes eventually. The specificity of HDPs toward bacteria cells over mammalian cells lies on the intrinsic difference between bacterial and mammalian cell membranes. It is known that the outer leaflet of mammalian cell membranes comprises zwitterionic lipids such as cholesterol, phosphatidylcholine, and sphingomyelin. Their negatively charged phospholipids are generally sequestered in the inner leaflet of membranes. ${ }^{2,8}$ In contrast, negatively charged phospholipids including cardiolipin and phosphatidylglycerol are frequently identified in the outer leaflet of bacterial membranes. ${ }^{9}$ In addition, negatively charged molecules such as teichoic acids and lipoteichoic acids are membrane components of most Gram-positive bacteria, while lipopolysaccharides are characteristic molecules on the outer membranes of Gram-negative bacteria. As a result, bacterial membrane surfaces are generally more negatively charged than those of mammalian cells, leading to interaction with cationic HDPs preferentially. Although detailed antimicrobial mechanism of HDPs are still under debate, a few models including barrel stave, carpet, toroidal pores have been proposed, all of which more or less possess surfactants-like behavior. ${ }^{2} 10$ For instance, lipopeptides have been considered as the most potent natural biosurfactants. ${ }^{11}$ As the interaction is based on physical charge—charge interaction and lacks defined membrane targets, it is believed that HDPs may decrease the risk of resistance development. ${ }^{12}$ This is also why HDPs possess broad-spectrum 
antibacterial activity and they are often bactericidal rather than bacteriostatic observed for most conventional antibiotics. ${ }^{2}$ It should be noted that some HDPs do have defined intracellular targets including proteins, nucleic acids, and ribosomes; however, their cationic amphipathic structure is still crucial for their entry into bacterial cells, and membrane disruption may be the additional mechanism of action that further synergizes their antimicrobial activity. ${ }^{9}$

Nevertheless, HDPs face considerable challenges for further antibiotic development, among which low stability, moderate activity, and cost for production are major obstacles. ${ }^{13}$ Oligomeric peptidomimetics are resistant to proteolytic degradation, and through optimization, peptidomimetics such as peptoids, ${ }^{14} \beta$-peptides, ${ }^{15-17}$ oligoureas,,${ }^{18}$ and AApeptides ${ }^{19-24}$ can mimic the structure and function of HDPs and show potent and broadspectrum activity against multidrug- resistant bacterial pathogens. Thus, they hold promise for future development of new class of antimicrobial agents. However, their structural complexity and large molecular weights (>1500 Da) make the synthetic process tedious and time-consuming, significantly hindering the translation of HDPs into clinical applications. To overcome the drawbacks, considerable endeavors have been devoted to the development of small molecular mimetics of HDPs of simplicity. Examples include arylamide foldamers, ${ }^{25}$ small peptoid mimics, ${ }^{26,27} \beta$-amino acid derivatives, ${ }^{28}$ dipeptide derivatives, ${ }^{29}$ and aryl compounds. ${ }^{30}$ In particular, it is exciting to witness that arylamide foldamers PMX series and dipeptide derivatives LTX compounds are currently in either phase II or phase III clinical trials (Figure 1), demonstrating the therapeutic potential of small HDP-mimicking antibiotic agents.

Reduced amide derivatives are peptides containing reduced amide bond and have been widely used as isosteric replacements for peptides (Figure 2). ${ }^{31}$ Even with one amide bond reduced to give secondary amine, the peptide sequences display significantly enhanced resistance to enzymatic degradation in contrast to canonical peptides. ${ }^{31}$ Recently there is growing interest in the exploration of biological application of reduced- amide-containing compounds, such as the use as enzyme inhibitors, ${ }^{32}$ analogues of endogenous peptides, ${ }^{33}$ synthetic vaccines, ${ }^{34}$ and DNA-complexing agents for gene delivery. ${ }^{35}$ Several reducedamide-containing sequences were also reported to mimic HDPs, as they are more resistant to proteolytic degradation. ${ }^{36}$ Indeed, AApeptides as oligomeric acylated reduced-amides were shown to display broad-spectrum antibacterial activity. ${ }^{37,38}$ However, these reduced-amidecontaining oligomers are fairly long and large (MW > 1800) sequences, and therefore their further optimization and potential for antibiotic therapeutics are still limited.

\section{RESULTS AND DISCUSSION}

To identify antibiotic agents with potentially more practical applications, herein we report the design and development of a class of small antimicrobial molecules containing acylated reduced amide (Figure 1). They are essentially built on a reduced dipeptide scaffold but with variable side chains. We hypothesized that if $R_{1}$ is a cationic group, while $R_{2}, R_{3}$, and $R_{4}$ are hydrophobic, the global structure of the molecules should be amphipathic, and thus they are expected to mimic HDPs and kill bacterial via membrane disruption. We anticipated that there are advantages associated with the molecular design. Reduced amide has been 
demonstrated for their biological potential and stability. The design is also very straightforward and universal, as functional groups can be introduced very easily. Moreover, the activity of the molecules could be tuned by varying the hydrophobicity of $R_{2}, R_{3}$, and $R_{4}$ groups. As such, it is intriguing to investigate the antimicrobial activity of this class of small molecules and to evaluate their potential as antibiotic therapeutics.

The synthesis of these molecules was straightforward (Figure 3; see Supporting Information for details). Briefly, the building block ${ }^{39}$ bearing the $\mathrm{R}_{2}$ side chain was attached to chlorotrityl resin. After Fmoc group was removed, the $\mathrm{R}_{3}$ moiety was attached to the secondary amine. Next, the alloc protecting group was removed, followed by capping with the $\mathrm{R}_{1}$ group. The molecule was then cleaved from the solid support, to which the $\mathrm{R}_{4}$ functionality was appended to the $\mathrm{C}$-terminus to give the final product. We synthesized a series of such small molecules, and the structures of some lead compounds are shown in Table 1. Their antibacterial activity was also tested against a few clinically relevant bacteria, including multidrug resistant Gram-positive and Gram-negative bacterial pathogens (Table 1). ${ }^{23,40}$

As shown in Table 1, with MWs ranging from 600 to 800, many molecules have shown good antibacterial activity against a panel of multidrug-resistant Gram-positive and Gram-negative bacteria. The structure-activity relationship is also obvious in this class of molecules, allowing for their further optimization and development in the future. In compound $\mathbf{1}, \mathrm{R}_{1}$ and $\mathrm{R}_{4}$ are hydrophobic naphthyl groups, while $\mathrm{R}_{2}$ and $\mathrm{R}_{3}$ are cationic groups. This compound did not show any antibacterial activity at the tested condition, possibly because the structure does not have segregated hydrophobic and cationic domains. We next kept $R_{1}$ as a cationic group and started to change the hydrophobicity of $R_{2}, R_{3}$, and $R_{4}$. As seen in compounds $\mathbf{2 - 4}$, when $R_{2}$ is hydrophilic, the compounds were still not effective, albeit compound $\mathbf{2}$ exhibited some activity against all strains. This is likely due to the insufficient hydrophobicity of the molecules which do not endow the molecules with membrane activity. However, when $\mathrm{R}_{2}, \mathrm{R}_{3}$, and $\mathrm{R}_{4}$ groups are all hydrophobic, compound $\mathbf{5}$ started to show activity against both Gram-positive and Gram-negative bacteria. It suggested that all $R_{2}, R_{3}$, and $\mathrm{R}_{4}$ groups have to be hydrophobic so as to possess sufficient interactions with bacterial membranes. We also noticed that the guanidino cationic group is slightly weaker than the amino group in eliciting antimicrobial activity; thus we focused on the development of derivatives containing cationic amino groups. It was found that the antibacterial activity is highly related to the overall hydrophobicity of $R_{2}, R_{3}$, and $R_{4}$. Change of $R_{3}$ to adamantyl group seemed to significantly improve the antimicrobial activity of $\mathbf{7}$, as its MIC against MRSE was $6.25 \mu \mathrm{g} / \mathrm{mL}$ already. When $\mathrm{R}_{4}$ became more hydrophobic, for instance, being two phenyl groups, or biphenyl group, the activity of compounds 8 and 9 was further improved to be around $6.25 \mu \mathrm{g} / \mathrm{mL}$ for most of strains. Substitution on the aromatic group on $\mathrm{R}_{4}$ was also likely to boost activity, as seen for $\mathbf{1 0}, \mathbf{1 1}$, and $\mathbf{1 2}$, which contain the $\mathrm{CF}_{3}$ or tertbutyl groups on the aromatic ring and displayed further enhanced activity. For instance, both $\mathbf{1 1}$ and $\mathbf{1 2}$ had the activity of less than $6.25 \mu \mathrm{g} / \mathrm{mL}$ for all tested strains. It should be noted that these compounds are quite selective, as their hemolytic activity are all more than 100 $\mu \mathrm{g} / \mathrm{mL}$. We hypothesized that the antibacterial activity could be further enhanced by increasing the hydrophobicity of $\mathrm{R}_{4}$, and thus compound $\mathbf{1 3}$ was designed. This compound 
contained adamantyl groups on both $\mathrm{R}_{3}$ and $\mathrm{R}_{4}$ positions, and as anticipated, it displayed more potent activity against MRSA with MIC of $1.56 \mu \mathrm{g} / \mathrm{mL}$. It is known that hemolytic activity could be mitigated through the introduction of cationic charges. ${ }^{43}$ We next designed the compound 14 , which contained one more lysine residue on the $\mathrm{R}_{1}$ position compared with 13. As expected, with one more cationic charge, compound 14 exhibited less hemolytic activity. However, the antibacterial activity of compound $\mathbf{1 4}$ was also less than 13. Similar results were observed for $\mathbf{1 5}$ and $\mathbf{1 6}$ as well, suggesting that more lysine residues may not be preferred for bacterial killing. It is also interesting that with the replacement of lysine residue in $\mathbf{1 4}$ by an ornithine residue, compound $\mathbf{1 5}$ shows slightly increased hemolytic activity, even though the overall cationic charges remain the same. It may be because the side chain of lysine is slightly longer than that of ornithine, which decreases the potential nonspecific interactions. In addition, replacement of the lysine residue with arginine residue did not impact significantly either on antibacterial activity or on hemolytic activity, as seen for $\mathbf{1 4}$ and 16, both of which show comparable selectivity toward bacteria. Next, we also tested the cytotoxicity of these compounds against HK-2 and K562 cells. Interestingly, although amphipathic agents are often cytotoxic, our compounds did not show noticeable cytotoxicity at the concentration of $25 \mu \mathrm{g} / \mathrm{mL}$ against both HK-2 and K562 cells. The lead compound 13 has $\mathrm{EC}_{50}$ of 86.3 and $83.2 \mu \mathrm{g} / \mathrm{mL}$ against HK-2 and K562 cells, respectively, $>50$-fold of selectivity for MRSA.

As these acylated reduced-amide molecules were designed to possess global amphipathic structure of HDPs, we hypothesized they could mimic the mechanism of action of HDPs and exert their bactericidal activity by disrupting bacterial membranes. To evaluate the ability of these compounds to compromise bacterial membranes, fluorescence microscopy was used to visualize the impact of compounds on membranes of $S$. aureus. ${ }^{19}$ Although 11-13 have similar activity against the tested panel of bacteria, $\mathbf{1 3}$ and $\mathbf{1 4}$ were chosen in the study, as they show most potent activity in killing MRSA. Two dyes, 4',6-diamidino-2-phenylindole (DAPI) and propidium iodide (PI) (Figure 4), were employed in the study. It is known that DAPI could stain membranes of bacterial cells with blue fluorescence irrespective of cell viability; however, the red fluorescence of PI due to the DNA intercalation could only be observed in the presence of impaired membranes that are permeable to PI. As shown in Figure 4, in the DAPI channel $(460 \mathrm{~nm}), S$. aureus species in the control groups are visible. However, they are not visible under the PI channel $(620 \mathrm{~nm})$. After bacteria were incubated with either 13 or 14, they fluoresce under both PI and DAPI channels, suggesting the membranes of $S$. aureus were damaged.

It is known that membrane-active antibiotic agents could exert their bactericidal activity very rapidly, a phenomenon that has been widely observed in HDPs. ${ }^{44}$ We thus next conducted time-kill study to investigate if $\mathbf{1 3}$ and $\mathbf{1 4}$ could rapidly kill MRSA in a dose-dependent fashion. Cell colonies were counted in agar plates at different time points at 4-, 8-, 16-fold of the MIC. As shown in Figure 5, compounds $\mathbf{1 3}$ and $\mathbf{1 4}$ at the concentration of either 25 or 50 $\mu \mathrm{g} / \mathrm{mL}$ could remove all bacteria completely in just $2 \mathrm{~h}$. This observation indicates that $\mathbf{1 3}$ and $\mathbf{1 4}$ act in a similar manner to that of HDPs.

It is known that HDPs do not induce resistance in bacteria readily because they disintegrate bacterial membranes, ${ }^{45}$ a mechanism lacking defined molecular targets. To evaluate the 
probability of these reduced-amide-based small molecules to elicit resistance in bacteria, we carried out the drug resistance studies of $\mathbf{1 3}$ and $\mathbf{1 4}$ against MRSA. Their MICs toward MRSA were first measured, and then these compounds were incubated with bacteria in the well of the half-MIC and tested for their activity again. As shown in Figure 6, after 14 passages, MICs of both $\mathbf{1 3}$ and $\mathbf{1 4}$ are virtually very constant, indicating that these compounds do not induce drug resistance in MRSA, which suggests their mode of action is analogous to that of HDPs.

The biofilm is a notorious problem because bacteria in biofilm are generally more difficult to eradicate than planktonic cells. Thus, it could lead to severe chronic infectious diseases which complicate the treatment. In addition, the biofilm is also known to contaminate medical devices contributing to hospital acquired infections. ${ }^{46}$ The biofilms formed by Gram-negative bacteria are even more challenging due to their stronger resistance. It is known than biofilms of E. coli and A. baumannii have posted great threat to community, and thus compounds that prevent their biofilm formation could lead to novel therapeutics. ${ }^{47,48}$ To evaluate the potential of the reduced-amide derived molecules in the biofilm prevention, compound $\mathbf{1 3}$ was evaluated for its ability to inhibit the biofilm formation of $E$. coii and $A$. baumannii. As shown in Figure 7, at just a concentration of $0.6 \mu \mathrm{g} / \mathrm{mL}, \mathbf{1 3}$ could inhibit more than $50 \%$ of biofilm formation of both $E$. coii and A. baumannii. At the concentration of $2 \mu \mathrm{g} / \mathrm{mL}$, it almost completely eradicated their biofilms.

Pneumonia is one of the most severe diseases caused by bacterial infection. ${ }^{49}$ Communityacquired MRSA induced pneumonia has led to significant medicare cost and modality. Encouraged by the in vitro antibacterial profiles of our compounds, we tested their efficacy on a rat model bearing MRSA-induced ventilator-associated pneumonia ${ }^{50}$ in order to evaluate their therapeutic potential. In this model anti-inflammatory activity is used as a surrogate for clearing the infection. The pathological analysis (Figure 8a) shows that local nasal administration of MRSA infection stimulated acute inflammation response in lungs, as indicated by the prevalence of neutrophils (blue spots in H\&E staining). In the control group that was treated with saline, typical inflammation caused by pneumonia persisted over 3 days. In contrast, significant reduction of lung infiltrated proinflammatory cells could be observed after iv administration of compound $\mathbf{1 3}(10 \mathrm{mg} / \mathrm{kg})$, strongly supporting the effectiveness of our antibacterial agents. To further support the observation, the level of the inflammatory cytokine TNF- $a$ was also quantified by the ELISA assay. As shown in Figure $8 \mathrm{~b}$, the level of TNF- $a$ cytokine increased over time in bronchoalveolar lavage fluid from the control rat group that received saline only, suggesting the persistence of lung inflammation. However, with the treatment of 13, the cytokine level was lowered even after 1 day. At 3 days after treatment, the level of TNF- $a$ level decreased, which was almost half of the level in control. The in vivo studies suggest that the compound $\mathbf{1 3}$ is capable of effectively suppressing the acute lung inflammation caused by pneumonia.

\section{CONCLUSIONS}

To summarize, we have developed a series of small antimicrobial agents based on the acylated reduced amide scaffold. These molecules display good potency against a panel of multidrug-resistant Gram-positive and Gram-negative bacteria. Although other antimicrobial 
mechanisms cannot be excluded, our mechanistic studies suggest that these compounds could kill bacteria rapidly by disrupting bacterial membranes, a mechanism analogous to that of host-defense peptides (HDPs). The hypothesis is further supported by the fact that the susceptibility of MRSA bacteria to the lead compounds remains nearly unchanged even after 14 passages. Meanwhile, they also exhibit high potency to inhibit the formation of biofilms. Furthermore, anti-inflammatory potential of these molecules was confirmed in the MRSAinduced pneumonia-bearing rat model. Although these types of agents have moderate to good selectivity so far, our work sheds light on the development of more potent compounds. Compared to HDPs, facile synthesis and high cost-effectiveness of these compounds make them appealing classes of antibiotic agents combating drug-resistant bacterial strains.

Further studies on optimization of activity and selectivity, as well pharmacokinetic analysis, are underway in our lab.

\section{EXPERIMENTAL SECTION}

\section{General Information}

All Fmoc protected $a$-amino acids and Rink-amide resin ( $0.7 \mathrm{mmol} / \mathrm{g}, 200-400 \mathrm{mesh})$ were purchased from Chem-Impex International, Inc. Solvents and other reagents were purchased from either Sigma-Aldrich or Fisher Scientific and were used without further purification.

Solid-phase synthesis of the compounds was carried out in the peptide synthesis vessel on a Burrell wrist-action shaker. The products were purified on a Waters Breeze 2 HPLC system, and lyophilized on a Labconco lyophilizer. The purity of the compounds was determined to be $>95 \%$ by analytical HPLC ( $1 \mathrm{~mL} / \mathrm{min}$ flow, $5-100 \%$ linear gradient of solvent B $(0.1 \%$ TFA in acetonitrile) in A ( $0.1 \%$ TFA in water) over 40 min was used). The NMR spectra were obtained on a Varian Inova 400 instrument.

\section{Synthesis of Desired Compounds}

Synthesis of 7 is shown below. The other compounds were synthesized following the similar procedure of 7. 2-Chlorotrityl chloride (CTC) resin ( $200 \mathrm{mg}, 0.2 \mathrm{mmol}$ ) was swelled in 3 $\mathrm{mL}$ of DCM for $15 \mathrm{~min}$. The attachment of the first building block to the resin was achieved by adding $\gamma$-BB-1 (154 mg, $0.3 \mathrm{mmol}$ ) and $N, N$-diisopropylethylamine (DIPEA) (173 $\mu \mathrm{L}, 1$ $\mathrm{mmol}$ ) to the beads in the reaction vessel, which was allowed to shake at room temperature for $2 \mathrm{~h}$. After that, the reaction solution was drained, followed by washing with DMF ( $2 \mathrm{~mL}$ $\times 3)$ and DCM $(2 \mathrm{~mL} \times 3)$. The unreacted 2-chlorotrityl chloride moieties were capped with $3 \mathrm{~mL}$ of methanol for $30 \mathrm{~min}$. The beads were washed with DCM $(3 \mathrm{~mL} \times 3)$ and DMF (3 $\mathrm{mL} \times 3)$. The Fmoc group was removed by treating beads with $20 \%$ piperidine/DMF (v/v) solution for $10 \mathrm{~min}(\times 2)$ at room temperature. The solution was drained and washed with $\operatorname{DMF}(3 \mathrm{~mL} \times 3)$ and DCM $(3 \mathrm{~mL} \times 3)$. The beads were reacted with 1-admantaneacetyl chloride ( $72 \mu \mathrm{L}, 0.4 \mathrm{mmol})$ and DIPEA ( $87 \mu \mathrm{L}, 0.5 \mathrm{mmol})$ for $30 \mathrm{~min}(\times 2)$ at room temperature, and the solution was removed. After DMF $(2 \mathrm{~mL} \times 3)$ and DCM $(2 \mathrm{~mL} \times 3)$ wash, the beads were treated with $\mathrm{Pd}\left(\mathrm{PPh}_{3}\right)_{4}(24 \mathrm{mg}, 0.02 \mathrm{mmol})$ and $\mathrm{Me}_{2} \mathrm{NHÇBH}_{3}(70 \mathrm{mg}$, $1.2 \mathrm{mmol})$ in $2 \mathrm{~mL}$ of DCM for $10 \mathrm{~min}(\times 2)$ to remove the alloc protecting group. After the reaction, the solution was drained, and the beads were washed with DCM $(3 \mathrm{~mL} \times 3)$ and DMF (3 mL ×3). Next, Fmoc-Lys(Boc)-OH (187 mg, $0.4 \mathrm{mmol}), N, N-$ diisopropylcarbodiimide (DIC) $(84 \mu \mathrm{L}, 0.8 \mathrm{mmol})$, and hydroxybenzotriazole (HOBt) $(122$ 
$\mathrm{mg}, 0.8 \mathrm{mmol}$ ) were premixed in $2 \mathrm{~mL}$ of DMF for $5 \mathrm{~min}$ before getting transferred to the reaction vessel. The reaction was shaken at room temperature for $3 \mathrm{~h}$, and the solution was drained. Then the intermediate was cleaved from resin with $5 \mathrm{~mL}$ of the cleavage cocktail (acetic acid/2,2,2-trifluoroethanol/DCM 1:1:8, v/v/v) for $2 \mathrm{~h}$. The solution was collected, and the remaining beads were washed with $3 \mathrm{~mL}$ of the cleavage cocktail solution three times. All the solution was combined and concentrated in vacuo with coevaporation with hexane multiple times to completely remove acetic acid. A white solid intermediate was obtained. This intermediate was premixed with HOBt and DIC in DMF for 5 min, followed by the addition of 1-naphthylmethylamine. The clear faint yellow solution was stirred at room temperature for $5 \mathrm{~h}$, then water was added to quench the reaction, followed by ethyl acetate (EtOAc) extraction. The organic layer was washed with $1 \mathrm{M} \mathrm{HCl}(\times 3)$ then brine $(\times 1)$, dried over anhydrous $\mathrm{Na} 2 \mathrm{SO} 4$, and concentrated by vacuum. The residue was treated with 50\% TFA in DCM for $2 \mathrm{~h}$, and then the solvent was removed with the $\mathrm{N}_{2}$ flow. The residue was then treated with $50 \%$ diethylamine in $\mathrm{CH}_{3} \mathrm{CN}$ for 30 min to remove Fmoc protecting group, followed by the removal of the solvent. The crude was analyzed and prepared on Waters HPLC system, followed by lyophilization to give the pure product 7 .

\section{Compound 1}

${ }^{1} \mathrm{H}$ NMR (400 MHz, DMSO- $\left.d_{6}\right) \delta 8.26-8.65(\mathrm{~m}, 2 \mathrm{H}), 7.80-8.03(\mathrm{~m}, 5 \mathrm{H}), 7.54-7.79(\mathrm{~m}$, $6 \mathrm{H}), 7.37-7.53(\mathrm{~m}, 3 \mathrm{H}), 4.60-4.74(\mathrm{~m}, 1.5 \mathrm{H}), 4.23-4.28(\mathrm{~m}, 0.8 \mathrm{H}), 3.85-4.13(\mathrm{~m}, 2 \mathrm{H})$, 3.48-3.66 (brd m, overlapped with $\mathrm{H}_{2} \mathrm{O}, 4.5 \mathrm{H}$ ), 3.41 (dd, $J=14.8,9.2 \mathrm{~Hz}, 0.6 \mathrm{H}$ ), 3.26 (dd, $J$ $=14.8,9.2 \mathrm{~Hz}, 0.5 \mathrm{H}), 2.61-2.75(\mathrm{~m}, 3 \mathrm{H}), 2.50-2.59(\mathrm{~m}, 1 \mathrm{H}), 2.12-2.80(\mathrm{~m}, 0.8 \mathrm{H}), 1.26-$ $1.75(\mathrm{~m}, 6 \mathrm{H})$. HRMS (ESI) $\mathrm{C}_{34} \mathrm{H}_{42} \mathrm{~N}_{5} \mathrm{O}_{3}[\mathrm{M}+\mathrm{H}]^{+}$calcd $=568.3282$; found $=568.3271$.

\section{Compound 2}

${ }^{1} \mathrm{H}$ NMR (400 MHz, DMSO- $\left.d_{6}\right) \delta 8.99(\mathrm{t}, J=5.6 \mathrm{~Hz}, 0.3 \mathrm{H}), 8.47-8.52(\mathrm{~m}, 1 \mathrm{H}), 8.10$ (brd, 2H), 7.93 (d, $J=8.0 \mathrm{~Hz}, 2 \mathrm{H}$ ), 7.90 (s, 1H), 7.81 (t, $J=7.2 \mathrm{~Hz}, 2 \mathrm{H}$ ), 7.77 (brd, 1H), 7.69 (d, $J$ $=8.0 \mathrm{~Hz}, 1.3 \mathrm{H}), 7.42-7.59(\mathrm{~m}, 5 \mathrm{H}), 7.28(\mathrm{t}, J=7.2 \mathrm{~Hz}, 0.8 \mathrm{H}), 7.15(\mathrm{~d}, J=6.4 \mathrm{~Hz}, 0.7 \mathrm{H})$, 4.71-4.83 (m, 0.8H), 4.68 (brd, 1.4H), 4.00-4.39 (m, 2.6H), 3.69 (overlapped, 2H), 2.74$2.83(\mathrm{~m}, 2 \mathrm{H}), 1.21-1.60(\mathrm{~m}, 6 \mathrm{H})$. HRMS (ESI) $\mathrm{C}_{30} \mathrm{H}_{35} \mathrm{~N}_{4} \mathrm{O}_{2}[\mathrm{M}+\mathrm{H}]^{+}$calcd = 483.2755; found $=483.2756$.

\section{Compound 3}

${ }^{1} \mathrm{H}$ NMR (400 MHz, DMSO- $\left.d_{6}\right) \delta 8.59(\mathrm{t}, J=5.6 \mathrm{~Hz}, 0.4 \mathrm{H}), 8.36-8.41(\mathrm{~m}, 1 \mathrm{H}), 8.22(\mathrm{~d}, J=$ $8.8 \mathrm{~Hz}, 0.6 \mathrm{H}), 8.14$ (brd, $2 \mathrm{H}), 8.03(\mathrm{dd}, J=6.4,2.4 \mathrm{H}, 1 \mathrm{H}), 7.93(\mathrm{td}, J=5.6,1.8 \mathrm{~Hz}, 1 \mathrm{H})$, $7.80-7.86$ (m, 1.8H), 7.6 (brd, 4H), 7.39-7.54 (m, 3.5H), 4.73 (dd, $J=12.8,5.6 \mathrm{~Hz}, 1.8 \mathrm{H})$, $4.12(\mathrm{~d}, J=15.2 \mathrm{~Hz}, 0.5 \mathrm{H}), 3.93-4.08(\mathrm{~m}, 2 \mathrm{H}), 3.63-3.72(\mathrm{~m}, 3 \mathrm{H}), 3.32(\mathrm{dd}, J=15.2,4.8$ $\mathrm{Hz}, 1 \mathrm{H}), 3.08$ (dd, $J=13.6,8.0 \mathrm{~Hz}, 0.6 \mathrm{H}), 2.70-2.73(\mathrm{~m}, 3 \mathrm{H}), 2.40$ (d, $J=13.6 \mathrm{~Hz}, 1 \mathrm{H})$, $1.72-1.93(\mathrm{~m}, 4 \mathrm{H}), 1.47-1.63(\mathrm{~m}, 18 \mathrm{H}), 1.13-1.35(\mathrm{~m}, 5 \mathrm{H})$. HRMS (ESI) $\mathrm{C}_{37} \mathrm{H}_{57} \mathrm{~N}_{6} \mathrm{O}_{3}$ [M $+\mathrm{H}]^{+}$calcd $=633.4487$; found $=633.4485$.

\section{Compound 4}

${ }^{1} \mathrm{H}$ NMR (400 MHz, DMSO-d ${ }_{6}$ ) $\delta 8.34-8.64$ (m, 2H), 8.19 (brs, 2.8H), 7.90-7.99 (m, $3.5 \mathrm{H}), 7.70-7.81(\mathrm{~m}, 8 \mathrm{H}), 7.41-7.58(\mathrm{~m}, 4 \mathrm{H}), 7.26-7.32(\mathrm{~m}, 1 \mathrm{H}), 7.16(\mathrm{~d}, J=6.8 \mathrm{~Hz}, 0.6 \mathrm{H})$, 
4.78 (brd, $0.5 \mathrm{H}), 4.63$ (d, $J=5.2 \mathrm{~Hz}, 1.3 \mathrm{H}), 4.10-4.25$ (m, 1.4H), 3.96 (brd, $2 \mathrm{H}), 3.17$ (overlapped, 2H), 3.46-4.39 (m, 2H), 3.24-3.30 (m, 0.6H), 2.56-2.74 (m, 4.4H), 1.51-1.74 (m, 5H), 1.20-1.42 (m, 6H), 1.00-1.14 (m, 1H). HRMS (ESI) $\mathrm{C}_{36} \mathrm{H}_{46} \mathrm{~N}_{6} \mathrm{NaO}_{3}[\mathrm{M}+\mathrm{Na}]^{+}$ calcd $=633.3524 ;$ found $=633.3636$.

\section{Compound 5}

${ }^{1} \mathrm{H}$ NMR (400 MHz, DMSO-d $\left.{ }_{6}\right) \delta 8.66(\mathrm{t}, J=4.4 \mathrm{~Hz}, 0.3), 8.44-8.66(\mathrm{~m}, 1.5 \mathrm{H}), 8.16$ (brd, $2 \mathrm{H}), 7.96(\mathrm{t}, J=8.0 \mathrm{~Hz}, 3 \mathrm{H}), 7.85(\mathrm{t}, J=8.0 \mathrm{~Hz}, 2 \mathrm{H}), 7.76(\mathrm{brd}, 2 \mathrm{H}), 7.43-7.63(\mathrm{~m}, 4.8 \mathrm{H})$, 7.18-7.36 (m, 5H), 6.86-7.09 (m, 1H), 4.47-4.83 (m, 3.8H), 4.12-4.16 (m, 2.8H), 3.96-4.06 $(\mathrm{m}, 1.6 \mathrm{H}), 3.06-3.76(\mathrm{~m}, 2.5 \mathrm{H}), 2.78-2.92(\mathrm{~m}, 1.5 \mathrm{H}), 2.56-2.67(\mathrm{~m}, 1.7 \mathrm{H}), 1.31-1.78(\mathrm{~m}$, $6 \mathrm{H})$. HRMS (ESI) $\mathrm{C}_{39} \mathrm{H}_{44} \mathrm{~N}_{5} \mathrm{O}_{3}[\mathrm{M}+\mathrm{H}]^{+}$calcd $=630.3439$; found $=630.3424$.

\section{Compound 6}

${ }^{1} \mathrm{H}$ NMR (400 MHz, DMSO- $\left.d_{6}\right) \delta 8.37-8.62(\mathrm{~m}, 1.6 \mathrm{H}), 8.10-8.21(\mathrm{~m}, 3 \mathrm{H}), 7.90-7.97(\mathrm{~m}$, $3 \mathrm{H}), 7.80-7.84(\mathrm{~m}, 1.6 \mathrm{H}), 7.66-7.73(\mathrm{~m}, 1 \mathrm{H}), 7.37-7.58(\mathrm{~m}, 5 \mathrm{H}), 7.15-7.32(\mathrm{~m}, 6.6 \mathrm{H})$, 6.83-7.01 (m, 1.7H), 4.80-4.92 (m, 0.5H), 4.63-4.68 (m, 1H), 4.39-4.46 (m, 1H), 4.12-4.30 (m, 2H), 3.99 (d, $J=17.2 \mathrm{~Hz}, 2 \mathrm{H}), 3.82(\mathrm{dd}, J=13.6,6.4 \mathrm{~Hz}, 0.6 \mathrm{H}), 3.65-3.69(\mathrm{~m}, 1 \mathrm{H})$, 3.39-3.55 (m, 1H), 2.78-3.07 (m, 2H), 2.51-3.07 (m, 0,6H), 0.87-1.73 (m, 4H). HRMS (ESI) $\mathrm{C}_{39} \mathrm{H}_{44} \mathrm{~N}_{7} \mathrm{O}_{3}[\mathrm{M}+\mathrm{H}]^{+}$calcd $=658.3500$; found $=658.3496$.

\section{Compound 7}

${ }^{1} \mathrm{H}$ NMR $\left(400 \mathrm{MHz}\right.$, DMSO- $\left.d_{6}\right) \delta 8.57-8.63(\mathrm{~m}, 1 \mathrm{H}), 8.32-8.34(\mathrm{~m}, 1 \mathrm{H}), 8.01-8.09(\mathrm{~m}$, $3 \mathrm{H}), 7.92(\mathrm{dd}, J=9.6,6.0 \mathrm{~Hz}, 1 \mathrm{H}), 7.78-1.85(\mathrm{~m}, 3 \mathrm{H}), 7.40-7.53(\mathrm{~m}, 4 \mathrm{H}), 7.14-7.30(\mathrm{~m}$, $4 \mathrm{H}), 4.68-4.77(\mathrm{~m}, 2 \mathrm{H}), 4.07-4.21(\mathrm{~m}, 2 \mathrm{H}), 3.83-4.02(\mathrm{~m}, 4.8 \mathrm{H}), 3.66-3.69(\mathrm{~m}, 0.9 \mathrm{H})$, $3.47-3.58(\mathrm{~m}, 1.2 \mathrm{H}), 3.37-3.48(\mathrm{~m}, 1 \mathrm{H}), 3.15(\mathrm{dd}, J=13.6,7.6 \mathrm{~Hz}, 0.5 \mathrm{H}), 2.65-3.91(\mathrm{~m}$, 3.4H), 2.04-2.15 (m, 0.5H), 1.74-1.92 (m, 4H), 1.45-1.63 (m, 14H), 1.19-1.36 (m, 2.8H). HRMS (ESI) $\mathrm{C}_{40} \mathrm{H}_{54} \mathrm{~N}_{5} \mathrm{O}_{3}[\mathrm{M}+\mathrm{H}]^{+}$calcd $=652.4221$; found $=652.4204$.

\section{Compound 8}

${ }^{1} \mathrm{H}$ NMR (400 MHz, DMSO-d $\left.{ }_{6}\right) \delta 8.57(\mathrm{~d}, J=8.8 \mathrm{~Hz}, 0.5 \mathrm{H}), 8.31(\mathrm{~d}, J=8.8 \mathrm{~Hz}, 0.5 \mathrm{H})$, 8.05 (brd, 2H), 7.77 (brd, 2H), 7.15-7.38 (m, 16H), 4.61-4.67 (m, 0.5H), 4.25-4.57 (m, 5H), 4.13-4.18 (m, 1H), 4.00-4.08 (m, 1H),3.47-3.64 (m, 4H), 3.12 (dd, J=9.6, 7.2 Hz, 0.6H), $2.62-2.78(\mathrm{~m}, 4 \mathrm{H}), 2.25(\mathrm{~d}, J=13.6 \mathrm{~Hz}, 0.6 \mathrm{H}), 1.76-1.86(\mathrm{~m}, 3 \mathrm{H}), 1.52-1.72(\mathrm{~m}, 10 \mathrm{H})$, $1.38-1.47(\mathrm{~m}, 3 \mathrm{H}), 1.11-1.35(\mathrm{~m}, 6 \mathrm{H})$. HRMS (ESI) $\mathrm{C}_{43} \mathrm{H}_{58} \mathrm{~N}_{5} \mathrm{O}_{3}[\mathrm{M}+\mathrm{H}]^{+}$calcd $=$ 692.4534; found $=692.4517$.

\section{Compound 9}

${ }^{1} \mathrm{H}$ NMR (400 MHz, DMSO-d $\left.{ }_{6}\right) \delta 8.51-8.61(\mathrm{~m}, 0.8 \mathrm{H}), 8.29-8.33(\mathrm{~m}, 1 \mathrm{H}), 8.01-8.09(\mathrm{~m}$, 2.3H), 7.75 (brd, 2H), 7.54-7.61 (m, 3H), $7.42(\mathrm{t}, J=7.2 \mathrm{~Hz}, 2 \mathrm{H}), 7.14-7.34(\mathrm{~m}, 7 \mathrm{H}), 4.09-$ $4.31(\mathrm{~m}, 3 \mathrm{H}), 3.83-4.03(\mathrm{~m}, 2 \mathrm{H}), 3.67(\mathrm{~m}, 2 \mathrm{H}), 3.36-3.44(\mathrm{~m}, 2 \mathrm{H}), 2.17$ (dd, $J=13.6,8.0$ $\mathrm{Hz}, 0.6 \mathrm{H}), 2.51-2.78(\mathrm{~m}, 4 \mathrm{H}), 1.76-2.13(\mathrm{~m}, 4 \mathrm{H}), 1.43-1.61$ (m, 15H), 1.18-1.19 (m, 2H). HRMS (ESI) $\mathrm{C}_{42} \mathrm{H}_{56} \mathrm{~N}_{5} \mathrm{O}_{3}[\mathrm{M}+\mathrm{H}]+$ calcd $=678.4378$; found $=678.4365$. 


\section{Compound 10}

${ }^{1} \mathrm{H}$ NMR (400 MHz, DMSO-d $\left.\mathrm{d}_{6}\right) \delta 8.52-8.70(\mathrm{~m}, 1 \mathrm{H}), 8.31-8.42(\mathrm{~m}, 1 \mathrm{H}), 8.05-8.09$ (brdm, 2H), $7.75(\mathrm{~m}, 2 \mathrm{H}), 7.72(\mathrm{dd}, J=20.0,8.0 \mathrm{~Hz}, 2 \mathrm{H}), 7.43-7.48(\mathrm{~m}, 2 \mathrm{H}), 7.12-7.30(\mathrm{~m}, 5 \mathrm{H})$, 4,31-4,32 (m, 2H), 4.09-4.21 (m, 1H), 3.81-4.03 (m, 2H), 3.66-3.68 (m, 1H), 3.36-3.43 $(\mathrm{m}, 2 \mathrm{H}), 3.14(\mathrm{dd}, J=13.6,8.0 \mathrm{~Hz}, 0.5 \mathrm{H}), 2.51-2.78(\mathrm{~m}, 4 \mathrm{H}), 2.11(\mathrm{~d}, J=13.6 \mathrm{~Hz}, 0.5 \mathrm{H})$, 1.75-1.93 (m, 4H), 1.47-1.56 (brdm, 15H), 1.12-1.29 (m, 2H). HRMS (ESI) $\mathrm{C}_{37} \mathrm{H}_{51} \mathrm{~F}_{3} \mathrm{~N}_{5} \mathrm{O}_{3}[\mathrm{M}+\mathrm{H}]^{+}$calcd $=670.3939$; found $=670.3930$.

\section{Compound 11}

${ }^{1} \mathrm{H}$ NMR (400 MHz, DMSO-d 6 ) $\delta 8.43-8.57(\mathrm{~m}, 1 \mathrm{H}), 8.31(\mathrm{~d}, J=12.4 \mathrm{~Hz}, 0.4 \mathrm{H}), 8.21(\mathrm{t}, J$ $=5.6 \mathrm{~Hz}, 0.6 \mathrm{H}), 7.99-8.09(\mathrm{brdm}, 2.7 \mathrm{H}), 7.76(\mathrm{brd}, 2 \mathrm{H}), 7.12-7.35(\mathrm{~m}, 8 \mathrm{H}), 4.14-4.22(\mathrm{~m}$, $3 \mathrm{H}), 3.80-4.05(\mathrm{~m}, 3 \mathrm{H}), 3.65(\mathrm{~m}, 1 \mathrm{H}), 3.35-3.53(\mathrm{~m}, 3 \mathrm{H}), 3.16(\mathrm{dd}, J=13.6,8.0 \mathrm{~Hz}, 0.5 \mathrm{H})$, $2.51-2.91(\mathrm{~m}, 4 \mathrm{H}), 2.10(\mathrm{~d}, J=13.6 \mathrm{~Hz}, 0.6 \mathrm{H}), 1.72-1.94$ (m, 4H), 1.50-1.58 (brdm, 14H), 1.07-1.37 (m, 12H). HRMS (ESI) $\mathrm{C}_{40} \mathrm{H}_{60} \mathrm{~N}_{5} \mathrm{O}_{3}[\mathrm{M}+\mathrm{H}]^{+}$calcd $=658.4691$; found $=$ 658.4680 .

\section{Compound 12}

${ }^{1} \mathrm{H}$ NMR (400 MHz, DMSO- $d_{6}$ ) $\delta 8.77(\mathrm{dd}, J=12.0,6.0 \mathrm{~Hz}, 0.4 \mathrm{H}), 8.54(\mathrm{~d}, J=8.8 \mathrm{~Hz}$, $0.4 \mathrm{H}), 8.47$ (t, $J=6.0 \mathrm{~Hz}, 0.6 \mathrm{H}), 8.31(\mathrm{~d}, J=8.4 \mathrm{~Hz}, 0.4 \mathrm{H}), 8.04-8.08(\mathrm{brdm}, 2.7 \mathrm{H}), 7.97$ (s, $0.6 \mathrm{H}), 7.93$ (brs, 2H), 7.75 (brd, 2H), 7.14-7.29 (m, 4.6H), 4.41-4.46 (m, 2H), 4.15-4.20 (m, 1H), 3.81-4.10 (m, 3H), 3.59 (m, 1H), 3.35-3.53 (m, 2.6H), $3.13(\mathrm{dd}, J=13.6,8.0 \mathrm{~Hz}$, $0.4 \mathrm{H}), 2.51-2.85(\mathrm{~m}, 4 \mathrm{H}), 2.08(\mathrm{~d}, J=13.6 \mathrm{~Hz}, 0.5 \mathrm{H}), 1.63-1.87(\mathrm{~m}, 5 \mathrm{H}), 1.49-1.58$ (brdm, $14 \mathrm{H}), 1.20-1.31(\mathrm{~m}, 2 \mathrm{H})$. HRMS (ESI) $\mathrm{C}_{38} \mathrm{H}_{50} \mathrm{~F}_{6} \mathrm{~N}_{5} \mathrm{O}_{3}[\mathrm{M}+\mathrm{H}]^{+}$calcd $=738.3812$; found $=$ 738.3815 .

\section{Compound 13}

${ }^{1} \mathrm{H}$ NMR (400 MHz, DMSO- $d_{6}$ ) $\delta 8.57(\mathrm{t}, J=8.4 \mathrm{~Hz}, 0.4 \mathrm{H}), 8.34(\mathrm{t}, J=8.4 \mathrm{~Hz}, 0.5 \mathrm{H}), 8.08$ (brd, 2H), 7.89-7.94 (m, 0.6H), 7.78 (brd, 2H), 7.55-7.61 (m, 0.4), 7.18-7.27 (m, 4H), $4.12-4.22(\mathrm{~m}, 1 \mathrm{H}), 3.93-4.00(\mathrm{~m}, 1.3 \mathrm{H}), 3.62-3.78(\mathrm{~m}, 3.6 \mathrm{H}), 3.15-3.22(\mathrm{~m}, 0.7 \mathrm{H}), 2.73$ (brd, 5.3H), 2.42-2.55 (m, 2.2H), 2.13-2.18 (m, 0.3 H), 1.75-1.92 (m, 7H), 1.52-1.60 (brd, $20 \mathrm{H}$ ), 1.40 (brd, 7H), 1.20-1.27 (m, 2H). HRMS (ESI) $\mathrm{C}_{40} \mathrm{H}_{62} \mathrm{~N}_{5} \mathrm{O}_{3}[\mathrm{M}+\mathrm{H}]^{+}$calcd $=$ 660.4847 ; found $=660.4855$.

\section{Compound 14}

${ }^{1} \mathrm{H}$ NMR (400 MHz, DMSO- $\left.d_{6}\right) \delta 8.38-8.48(\mathrm{~m}, 1 \mathrm{H}), 8.14(\mathrm{brd}, 2 \mathrm{H}), 7.88-7.99(\mathrm{~m}, 1.4 \mathrm{H})$, 7.82 (brd, 3H), 7.51-7.57 (m, 0.4H), 7.11-7.25 (m, 4.6H), 3.95-3.18 (m, 3H), 3.67-3.76 (m, $1.5 \mathrm{H}), 3.51-3.52(\mathrm{~m}, 2 \mathrm{H}), 3.33-3.37(\mathrm{~m}, 2 \mathrm{H}), 3.02-3.12(\mathrm{~m}, 0.5 \mathrm{H}), 2.51-2.84(\mathrm{~m}, 8 \mathrm{H}), 2.20$ (dd, $J=13.6,8.0 \mathrm{~Hz}, 0.4 \mathrm{H}), 1.79-1.97(\mathrm{~m}, 7 \mathrm{H}), 1.44-1.64$ (brdm, 23H), 1.20-1.40 (m, $11 \mathrm{H}), 0.94(\mathrm{dd}, J=14.8,7.2 \mathrm{~Hz}, 1 \mathrm{H})$. HRMS (ESI) $\mathrm{C}_{46} \mathrm{H}_{74} \mathrm{~N}_{7} \mathrm{O}_{4}[\mathrm{M}+\mathrm{H}]^{+}$calcd $=$ 788.5797 ; found $=788.5797$.

\section{Compound 15}

${ }^{1} \mathrm{H}$ NMR (400 MHz, DMSO- $d_{6}$ ) $\delta 8.50-8.66(\mathrm{~m}, 1 \mathrm{H}), 8.20$ (brd, 2H), 7.95-8.18 (m, 1.8H), 7.80-7.88 (brd, 3H), 7.51- 7.62 (m, 0.5H), 7.11-7.27 (m, 4.7H), 3.90-4.18 (m, 7H),3.52- 
$3.82(\mathrm{~m}, 2.6 \mathrm{H}), 3.37-3.41(\mathrm{~m}, 1 \mathrm{H}), 2.96-3.96(\mathrm{~m}, 0.4 \mathrm{H}), 2.52-2.87(\mathrm{~m}, 8 \mathrm{H}), 1.78-2.18(\mathrm{~m}$, $8 \mathrm{H}), 1.30-1.69$ (brdm, 31H), 0.80-0.93 (m, 1H). HRMS (ESI) $\mathrm{C}_{45} \mathrm{H}_{72} \mathrm{~N}_{7} \mathrm{O}_{4}[\mathrm{M}+\mathrm{H}]^{+}$calcd $=774.5640$; found $=774.5651$.

\section{Compound 16}

${ }^{1} \mathrm{H}$ NMR (400 MHz, DMSO-d $\left.{ }_{6}\right) \delta 8.43-8.51(\mathrm{~m}, 1 \mathrm{H}), 8.15-8.21(\mathrm{~m}, 0.8 \mathrm{H}), 8.10$ (brd, $\left.2 \mathrm{H}\right)$, 7.86-8.02 (m, 1.2H), 7.73 (brd, 2H), 7.48-7.63 (m, 1.2H), 7.14-7.24 (m, 5H), 3.90-4.23 (m, $3.5 \mathrm{H}), 3.72-3.76(\mathrm{~m}, 1.5 \mathrm{H}), 3.50-3.55(\mathrm{~m}, 3 \mathrm{H}), 2.87-3.15(\mathrm{~m}, 3 \mathrm{H}), 2.57-2.79(\mathrm{~m}, 6 \mathrm{H})$, $1.82-1.95(\mathrm{~m}, 7 \mathrm{H}), 1.10-1.59(\mathrm{~m}, 33 \mathrm{H})$. HRMS (ESI) $\mathrm{C}_{46} \mathrm{H}_{74} \mathrm{~N}_{9} \mathrm{O}_{4}[\mathrm{M}+\mathrm{H}]^{+}$calcd $=$ 816.5858 ; found $=816.5866$.

\section{Minimum Inhibitory Concentrations (MICs) against Bacteria}

The antimicrobial activity of the compounds was tested on the following six bacteria strains: K. pneumoniae (ATCC 13383), P. aeruginosa (ATCC27853), E. coli (ATCC 25922), vancomycin- resistant Enterococcus faecalis (ATCC 700802), methicillin-resistant S. aureus (MRSA, ATCC 33591), methicillin-resistant S. epidermidis (MRSE, RP62A). The procedures were followed as reported previously. ${ }^{19}$ The MICs were determined as the lowest concentration that completely inhibits the bacteria growth. The experiments were repeated at least three times with duplicates each time.

\section{Hemolytic Assays}

The freshly drawn, K2EDTA treated human red blood cells (hRBCs) were washed with $1 \times$ PBS buffer and centrifuged at $3500 \mathrm{rpm}$ for $10 \mathrm{~min}$. The step was repeated until the supernatant became clear. The supernatant was removed, and the RBCs were diluted into 5\% $\mathrm{v} / \mathrm{v}$ suspension. $50 \mu \mathrm{L}$ of the suspension was incubated with $50 \mu \mathrm{L}$ of compounds of different concentrations at $37^{\circ} \mathrm{C}$ for $1 \mathrm{~h}$. The mixture was centrifuged at $3500 \mathrm{rpm}$ for 10 min. Subsequently, to $30 \mu \mathrm{L}$ of the supernatant, $100 \mu \mathrm{L}$ of PBS was added, and the absorbance of the mixture at $540 \mathrm{~nm}$ was read on a Biotek Synergy HT plate reader. The positive control was $2 \%$ Triton $\mathrm{X}-100$, and the negative control was $1 \times \mathrm{PBS}$ alone. The hemolysis activity was calculated by the formula $\%$ hemolysis $=\left[\left(\mathrm{Abs}_{\mathrm{sample}}-\mathrm{Abs} \mathrm{PBS}_{\mathrm{PS}}\right) /\right.$ $\left.\left(\mathrm{Abs}_{\text {Triton }}-\mathrm{Abs}_{\mathrm{PBS}}\right)\right] \times 100$. The experiment was repeated at least three times with duplicates each time.

\section{MTT Assays}

Both HK-2 and K562 cells were used to access the cell viability with treatment of compounds 5-16 using standard procedure. ${ }^{22}$ Cells were seeded in 96-well plate with $5 \times$ $10^{4}$ cells in $100 \mu \mathrm{L}$ of media per well. Control and blank wells were prepared accordingly. Serial dilutions of compounds at concentrations of $100,50,25,12.5,6.25 \mu \mathrm{g} / \mathrm{mL}$ were prepared by diluting stock solution with media. After incubation for $12 \mathrm{~h}, 100 \mu \mathrm{L}$ aliquots of drugs were added and the plate was incubated for $24 \mathrm{~h}$. All media in cells were then removed and washed with fresh media once, followed by addition of $110 \mu \mathrm{L}$ of 3-(4,5dimethylthiazol-2-yl)-2,5-diphenyltetrazolium bromide (MTT) reagent and then incubation for another $4 \mathrm{~h}$, after which $100 \mu \mathrm{L}$ of prewarmed solubilization solution was added. The plate was then incubated at $37{ }^{\circ} \mathrm{C}$ for $12 \mathrm{~h}$ before absorbance was read at $550 \mathrm{~nm}$. The data 
were calculated based on the following equation: Cell viability $\%=\left[\left(A-A_{\text {blank }}\right) /\left(A_{\text {control }}-\right.\right.$ $\left.\left.A_{\text {blank }}\right)\right] \times 100$. The measurements were repeated at least three times.

\section{Fluorescence Microscopy}

Fluorescence microscopy was used to assess the ability of the compounds to compromise bacterial membranes. Fluorescent dyes propidium iodide (PI) and 4', $6^{\prime}$ - diamidino-2phenylindole dihydrochloride (DAPI) were used in the study. DAPI stains bacteria cells irrespective of their viabilities, whereas PI can only permeate bacterial cells and intercalate DNA in order to fluoresce when bacterial cell membranes are damaged membranes. After MRSA grew to mid-logarithmic phase, $\mathbf{1 3}$ or $\mathbf{1 4}$ was incubated with the bacteria at $37^{\circ} \mathrm{C}$ for $2 \mathrm{~h}$. The mixture was then centrifuged at $5000 \mathrm{rpm}$ for $15 \mathrm{~min}$. The cell pellets were washed with the PBS buffer three times and incubated with PI $(5 \mu \mathrm{g} / \mathrm{mL})$ and DAPI $(10 \mu \mathrm{g} / \mathrm{mL})$ for 15 min sequentially on ice in the dark. The mixture was then centrifuged, and the pellets were washed with the PBS buffer. Next, an amount of $10 \mu \mathrm{L}$ of the samples was placed on chamber slides and observed under Zeiss Axio Imager Zl optical microscope using 100xoilimmersion objective.

\section{Time-Kill Study}

The kinetics of bacteria killing by the lead compounds 13 and 14 were investigated. Briefly, the bacteria MRSA grew to mid-logarithmic phase in tryptic soy broth (TSB) medium, from which the suspension $\left(10^{6}\right.$ colony-forming units per milliliter $\left.(\mathrm{CFU} / \mathrm{mL})\right)$ was made. The suspension was incubated with different concentrations of $\mathbf{1 3}$ or $\mathbf{1 4}$ for $10 \mathrm{~min}, 30 \mathrm{~min}, 1 \mathrm{~h}$, and $2 \mathrm{~h}$, respectively. The mixtures were diluted by $10^{2}$ - to $10^{4}$-fold and spread on TSB agar plates. After incubation at $37{ }^{\circ} \mathrm{C}$ overnight, the colonies on the plates were counted and plotted against the incubation time.

\section{Drug Resistance Study}

The initial MICs of compounds $\mathbf{1 3}$ and $\mathbf{1 4}$ for MRSA were obtained as above. Bacteria in wells containing a concentration of $1 / 2 \mathrm{MIC}$ were used to make bacterial suspension $\left(10^{6}\right.$ $\mathrm{CFU} / \mathrm{mL}$ ) for the next measurement of MICs of $\mathbf{1 3}$ and $\mathbf{1 4}$. The experiment was repeated each day for 14 passages.

\section{Inhibition of Biofilms}

Overnight grown bacteria were inoculated into fresh 10\% of MHII broth at a ratio of 1:100. $100 \mu \mathrm{L}$ of inoculated culture was incubated with an appropriate amount of compound $\mathbf{1 3}$ in wells of 96-well plate. The plate was incubated at $37^{\circ} \mathrm{C}$ overnight. Optical density of each well was recorded at a wavelength of $600 \mathrm{~nm}$, and then the biofilm biomass was recorded by the crystal violet method. Biofilm biomass was presented as CV OD/OD of growth. Relative biofilm biomass values were normalized by the biomass value of control (no addition of compound). Experiments were conducted in triplicate, and the data were presented as the mean \pm STDEV. 


\section{In Vivo Study. Establishment of the Rat Model of MRSA- Induced Pneumonia}

All animal experiments were approved by the Institutional Committee for Animal Care of Nanjing University and carried out in accordance to the policy of the National Ministry of Health of China. Briefly, male Wistar rats (6-8 weeks, average weight $200 \mathrm{~g}$ ) were subjected to fasting for at least $12 \mathrm{~h}$ prior to treatment. Then they were anesthetized with $1 \mathrm{~g} / \mathrm{kg}$ of urethane administered intraperitoneally. An endotracheal tube with the 16 gauge needle front was inserted into the trachea. After the placement of catheter, a stethoscope was used to confirm the catheter was right in the trachea. Next, $100 \mu \mathrm{L}$ of PBS containing $2 \times 10^{5}$ $\mathrm{CFU} / \mathrm{mL}$ MRSA was injected slowly to induce pneumonia. During the procedure, the rats were ventilated with a constant-volume respirator, and parameters were set as the following: inspired $\mathrm{O}_{2}$ fraction of 1.0; peak airway pressures of 8-12 $\mathrm{cm}$ of $\mathrm{H}_{2} \mathrm{O}$ and a $2 \mathrm{~cm}$ positive end expiratory pressure (PEEP); as high as $12 \mathrm{~mL} / \mathrm{kg}$ tidal volume was given every $30 \mathrm{~min}$ to avoid potential positional pulmonary atelectasis; breathing frequency was controlled at 70 times/min. The respiratory rate was adjusted to maintain the pressure of $\mathrm{CO}_{2}$ between 35 and $45 \mathrm{mmHg}$.

\section{Pathological Analysis}

A dose of $10 \mathrm{mg} / \mathrm{kg}$ weight of compound 13 was injected into the tail veins of tested rats intravenously. Time course profiles of histological changes in lungs of rats were assessed after intravenous injection followed by dissection after being euthanized. Sections from lungs were stained with hematoxylin and eosin (H\&E) and observed under a light microscope. For pathological investigation of lungs of pneumonia suffering rats at different time points, sections were collected as above-mentioned and existence (indicated by the infiltration of neutrophils) and the extent of possible inflammatory response (indicated by the integrity of the alveolar structure and endothelium cilium) were recorded from five randomly picked sections.

\section{Bronchoalveolar Lavage (BAL) Assay}

The assay was conducted to estimate the situation of inflammatory reactions in lungs. Rats were sacrificed and exsanguinated via the femoral vessel under sterile condition. Then the thorax was opened, and the 18 gauge needle was introduced to the trachea at the cricothyroid membrane. Subsequently, $1 \mathrm{~mL}$ of sterilized PBS was administrated and extracted out for six cycles to promote the elution of inflammatory cells. Upon treatment, each specimen was homogenized. The suspension was subjected to enzyme linked immunosorbent assay (Elisa, $\mathrm{R} \& \mathrm{D})$, and the level of tumor necrosis factor $a$ (TNF- $a$ ) cytokine was investigated.

\section{Supplementary Material}

Refer to Web version on PubMed Central for supplementary material.

\section{Acknowledgments}

This work was supported by NSF CAREER Grant 1351265 and NIH Grant 1R01GM112652-01A1. 


\section{ABBREVIATIONS}

MRSE methicillin-resistant Staphylococcus epidermidis

E. coli Escherichia coli

HDP host-defense peptide

MIC minimum inhibitory concentration

DAPI 4', 6-diamidino-2-phenylindole

PI propidium iodide

CTC 2-chlorotrityl chloride

DIPEA $\quad N, N$-diisopropylethylamine

DIC $\quad N, N$-diisopropylcarbodiimide

HOBt hydroxybenzotriazole

EtOAc ethyl acetate

hRBC human red blood cell

TSB tryptic soy broth

CFU colony-forming unit

PEEP positive end expiratory pressure

H\&E hematoxylin and eosin

BAL bronchoalveolar lavage

\section{References}

1. Niu Y, Wang RE, Wu H, Cai J. Recent development of small antimicrobial peptidomimetics. Future Med Chem. 2012; 4:1853-1862. [PubMed: 23043481]

2. Marr AK, Gooderham WJ, Hancock RE. Antibacterial peptides for therapeutic use: obstacles and realistic outlook. Curr Opin Pharmacol. 2006; 6:468-472. [PubMed: 16890021]

3. WHO. Antimicrobial resistance: global report on surveillance. World Health Organization; 2014.

4. Brown KL, Hancock REW. Cationic host defense (antimicrobial) peptides. Curr Opin Immunol. 2006; 18:24-30. [PubMed: 16337365]

5. Hancock RE, Sahl HG. Antimicrobial and host-defense peptides as new anti-infective therapeutic strategies. Nat Biotechnol. 2006; 24:1551-1557. [PubMed: 17160061]

6. Mercer DK, O'Neil DA. Peptides as the next generation of anti-infectives. Future Med Chem. 2013; 5:315-337. [PubMed: 23464521]

7. Fjell CD, Hiss JA, Hancock REW, Schneider G. Designing antimicrobial peptides: form follows function. Nat Rev Drug Discovery. 2012; 11:37-51.

8. Hancock REW, Brown KL, Mookherjee N. Host defence peptides from invertebrates - emerging antimicrobial strategies. Immunobiology. 2006; 211:315-322. [PubMed: 16697922]

9. Matsuzaki K. Control of cell selectivity of antimicrobial peptides. Biochim Biophys Acta, Biomembr. 2009; 1788:1687-1692. 
10. Sengupta D, Leontiadou H, Mark AE, Marrink SJ. Toroidal pores formed by antimicrobial peptides show significant disorder. Biochim Biophys Acta Biomembr. 2008; 1778:2308-2317.

11. Fernandes PAV, Arruda IRd, Santos AFABd, Araujo AAd, Maior AMS, Ximenes EA. Antimicrobial activity of surfactants produced by Bacillus subtilis R14 against multidrug- resistant bacteria. Braz J Microbiol. 2007; 38:704-709.

12. Tew GN, Scott RW, Klein ML, Degrado WF. De novo design of antimicrobial polymers, foldamers, and small molecules: from discovery to practical applications. Acc Chem Res. 2010; 43:30-39. [PubMed: 19813703]

13. Chongsiriwatana NP, Patch JA, Czyzewski AM, Dohm MT, Ivankin A, Gidalevitz D, Zuckermann RN, Barron AE. Peptoids that mimic the structure, function, and mechanism of helical antimicrobial peptides. Proc Natl Acad Sci U S A. 2008; 105:2794-2799. [PubMed: 18287037]

14. Patch JA, Barron AE. Helical peptoid mimics of magainin-2 amide. J Am Chem Soc. 2003; 125:12092-12093. [PubMed: 14518985]

15. Karlsson AJ, Pomerantz WC, Weisblum B, Gellman SH, Palecek SP. Antifungal activity from 14helical beta-peptides. J Am Chem Soc. 2006; 128:12630-12631. [PubMed: 17002340]

16. Porter EA, Weisblum B, Gellman SH. Mimicry of host- defense peptides by unnatural oligomers: antimicrobial beta-peptides. J Am Chem Soc. 2002; 124:7324-7330. [PubMed: 12071741]

17. Porter EA, Wang X, Lee HS, Weisblum B, Gellman SH. Antibiotics: Non-haemolytic beta-aminoacid oligomers. Nature. 2000; 404:565. [PubMed: 10766230]

18. Violette A, Fournel S, Lamour K, Chaloin O, Frisch B, Briand JP, Monteil H, Guichard G. Mimicking helical antibacterial peptides with nonpeptidic folding oligomers. Chem Biol. 2006; 13:531-538. [PubMed: 16720274]

19. Niu Y, Padhee S, Wu H, Bai G, Qiao Q, Hu Y, Harrington L, Burda WN, Shaw LN, Cao C, Cai J. Lipogamma-AApeptides as a new class of potent and broad-spectrum antimicrobial agents. J Med Chem. 2012; 55:4003-4009. [PubMed: 22475244]

20. Teng P, Shi Y, Sang P, Cai J. Gamma-AApeptides as a new class of peptidomimetics. Chem - Eur J. 2016; 22:5458-5446. [PubMed: 26945679]

21. Shi Y, Teng P, Sang P, She F, Wei L, Cai J. gamma-AApeptides: Design, Structure, and Applications. Acc Chem Res. 2016; 49:428-441. [PubMed: 26900964]

22. Li Y, Wu H, Teng P, Bai G, Lin X, Zuo X, Cao C, Cai J. Helical antimicrobial sulfono-gammaAApeptides. J Med Chem. 2015; 58:4802-4811. [PubMed: 26020456]

23. Li Y, Smith C, Wu H, Padhee S, Manoj N, Cardiello J, Qiao Q, Cao C, Yin H, Cai J. Lipidated cyclic gamma-AApeptides display both antimicrobial and anti-inflammatory activity. ACS Chem Biol. 2014; 9:211-217. [PubMed: 24144063]

24. Wu H, Niu Y, Padhee S, Wang RE, Li Y, Qiao Q, Bai G, Cao C, Cai J. Design and synthesis of unprecedented cyclic gamma-AApeptides for antimicrobial development. Chem Sci. 2012; 3:2570-2575.

25. Choi S, Isaacs A, Clements D, Liu D, Kim H, Scott RW, Winkler JD, DeGrado WF. De novo design and in vivo activity of conformationally restrained antimicrobial arylamide foldamers. Proc Natl Acad Sci U S A. 2009; 106:6968-6973. [PubMed: 19359494]

26. Ghosh C, Manjunath GB, Akkapeddi P, Yarlagadda V, Hoque J, Uppu DS, Konai MM, Haldar J. Small molecular antibacterial peptoid mimics: the simpler the better! J Med Chem. 2014; 57:1428-1436. [PubMed: 24479371]

27. Bremner JB, Keller PA, Pyne SG, Boyle TP, Brkic Z, David DM, Garas A, Morgan J, Robertson M, Somphol K, Miller MH, Howe AS, Ambrose P, Bhavnani S, Fritsche TR, Biedenbach DJ, Jones RN, Buckheit RW, Watson KM, Baylis D, Coates JA, Deadman J, Jeevarajah D, McCracken A, Rhodes DI. Binaphthyl-based dicationic peptoids with therapeutic potential. Angew Chem Int Ed. 2010; 49:537-540.

28. Hansen T, Alst T, Havelkova M, Strom MB. Antimicrobial activity of small beta-peptidomimetics based on the pharmacophore model of short cationic antimicrobial peptides. J Med Chem. 2010; 53:595-606. [PubMed: 19994905]

29. Isaksson J, Brandsdal BO, Engqvist M, Flaten GE, Svendsen JS, Stensen W. A synthetic antimicrobial peptidomimetic (LTX 109): stereochemical impact on membrane disruption. J Med Chem. 2011; 54:5786-5795. [PubMed: 21732630] 
30. Thaker HD, Som A, Ayaz F, Lui DH, Pan WX, Scott RW, Anguita J, Tew GN. Synthetic mimics of antimicrobial peptides with immunomodulatory responses. J Am Chem Soc. 2012; 134:1108811091. [PubMed: 22697149]

31. Zivec M, Jakopin Z, Gobec S. Recent advances in the synthesis and applications of reduced amide pseudopeptides. Curr Med Chem. 2009; 16:2289-2304. [PubMed: 19519391]

32. Coburn CA, Stachel SJ, Jones KG, Steele TG, Rush DM, DiMuzio J, Pietrak BL, Lai MT, Huang Q, Lineberger J, Jin L, Munshi S, Katharine Holloway M, Espeseth A, Simon A, Hazuda D, Graham SL, Vacca JP. BACE-1 inhibition by a series of $\psi\left[\mathrm{CH}_{2} \mathrm{NH}\right]$ reduced amide isosteres. Bioorg Med Chem Lett. 2006; 16:3635-3638. [PubMed: 16690314]

33. Todorovic A, Holder JR, Scott JW, Haskell-Luevano C. Synthesis and activity of the melanocortin Xaa-d-Phe-Arg-Trp-NH tetrapeptides with amide bond modifications. J Pept Res. 2004; 63:270278. [PubMed: 15049839]

34. Lozano JM, Alba MP, Vanegas M, Silva Y, Torres- Castellanos JL, Patarroyo ME. MSP-1 malaria pseudopeptide analogs: biological and immunological significance and three-dimensional structure. Biol Chem. 2003; 384:71-82. [PubMed: 12674501]

35. Fridkin G, Gilon C, Gilon T, Loyter A. Systematic solid- phase synthesis of linear pseudooligolysines containing multiple adjacent $\mathrm{CH}_{2} \mathrm{NH}$ amide bond surrogates: potential agents for gene delivery. J Pept Res. 2001; 58:36-44. [PubMed: 11454168]

36. Kim SM, Kim JM, Joshi BP, Cho H, Lee KH. Indolicidin-derived antimicrobial peptide analogs with greater bacterial selectivity and requirements for antibacterial and hemolytic activities. Biochim Biophys Acta, Proteins Proteomics. 2009; 1794:185-192.

37. Niu Y, Padhee S, Wu H, Bai G, Harrington L, Burda WN, Shaw LN, Cao C, Cai J. Identification of gamma-AApeptides with potent and broad-spectrum antimicrobial activity. Chem Commun. 2011; 47:12197-12199.

38. Niu Y, Wu H, Li Y, Hu Y, Padhee S, Li Q, Cao C, Cai J. AApeptides as a new class of antimicrobial agents. Org Biomol Chem. 2013; 11:4283-4290. [PubMed: 23722277]

39. Wu HF, She FY, Gao WY, Prince A, Li YQ, Wei LL, Mercer A, Wojtas L, Ma SQ, Cai JF. The synthesis of head- to-tail cyclic sulfono-gamma-AApeptides. Org Biomol Chem. 2015; 13:672676. [PubMed: 25420701]

40. Li Y, Smith C, Wu H, Teng P, Shi Y, Padhee S, Jones T, Nguyen AM, Cao C, Yin H, Cai J. Short antimicrobial lipo-alpha/ gamma-AA hybrid peptides. ChemBioChem. 2014; 15:2275-2280. [PubMed: 25169879]

41. Weis F, Beiras-Fernandez A, Schelling G. Daptomycin, a lipopeptide antibiotic in clinical practice. Curr Opin Invest Drugs. 2008; 9:879-884.

42. Yahav D, Farbman L, Leibovici L, Paul M. Colistin: new lessons on an old antibiotic. Clin Microbiol Infect. 2012; 18:18-29. [PubMed: 22168320]

43. Liu RH, Chen XY, Chakraborty S, Lemke JJ, Hayouka Z, Chow C, Welch RA, Weisblum B, Masters KS, Gellman SH. Tuning the biological activity profile of antibacterial polymers via subunit substitution pattern. J Am Chem Soc. 2014; 136:4410-4418. [PubMed: 24601599]

44. Ge Y, MacDonald DL, Holroyd KJ, Thornsberry C, Wexler H, Zasloff M. In vitro antibacterial properties of pexiganan, an analog of magainin. Antimicrob Agents Chemother. 1999; 43:782788. [PubMed: 10103181]

45. Bowdish DME, Davidson DJ, Lau YE, Lee K, Scott MG, Hancock REW. Impact of LL-37 on antiinfective immunity. J Leukocyte Biol. 2005; 77:451-459. [PubMed: 15569695]

46. Padhee S, Li Y, Cai J. Activity of lipo-cyclic gamma-AApeptides against biofilms of Staphylococcus epidermidis and Pseudomonas aeruginosa. Bioorg Med Chem Lett. 2015; 25:2565-2569. [PubMed: 25977094]

47. Wu J, Franzblau A, Xi C. Molecular characterization of microbial communities and quantification of Mycobacterium immunogenum in metal removal fluids and their associated biofilms. Environ Sci Pollut Res. 2016; 23:4086-4094.

48. Park SR, Tripathi A, Wu J, Schultz PJ, Yim I, McQuade TJ, Yu F, Arevang CJ, Mensah AY, Tamayo-Castillo G, Xi C, Sherman DH. Discovery of cahuitamycins as biofilm inhibitors derived from a convergent biosynthetic pathway. Nat Commun. 2016; 7:10710. [PubMed: 26880271] 
49. Rubinstein E, Kollef MH, Nathwani D. Pneumonia caused by methicillin-resistant Staphylococcus aureus. Clin Infect Dis. 2008; 46(Suppl. 5):S378-S385. [PubMed: 18462093]

50. Huo D, Ding J, Cui YX, Xia LY, Li H, He J, Zhou ZY, Wang HW, Hu Y. X-ray CT and pneumonia inhibition properties of gold-silver nanoparticles for targeting MRSA induced pneumonia. Biomaterials. 2014; 35:7032-7041. [PubMed: 24836950] 
Teng et al.

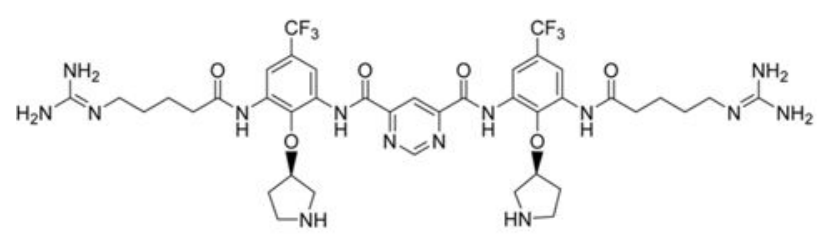

Brilacidin (PMX-30063)

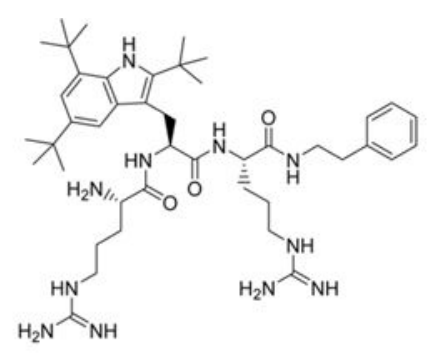

LTX-109
Page 18

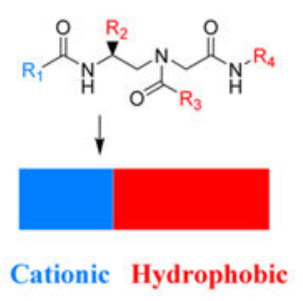

Acylated reduced amide in this study

Figure 1.

Structures of PMX-30063 and LTX-109 and design of small antimicrobial agents based on the acylated reduced amide. $\mathrm{R}_{1}$ represents cationic groups. $\mathrm{R}_{2}, \mathrm{R}_{3}$, and $\mathrm{R}_{4}$ represent hydrophobic groups. 
<smiles>[R]C(NC(=O)C([R])NC(=O)C([R])NC(=O)C([R])NC(=O)C([R])NC)C(N)=O</smiles>

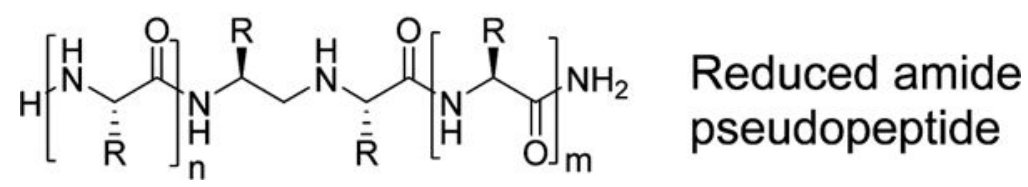

Figure 2.

General chemical structures of $\boldsymbol{a}$-peptide and reduced amide pseudopeptide. 

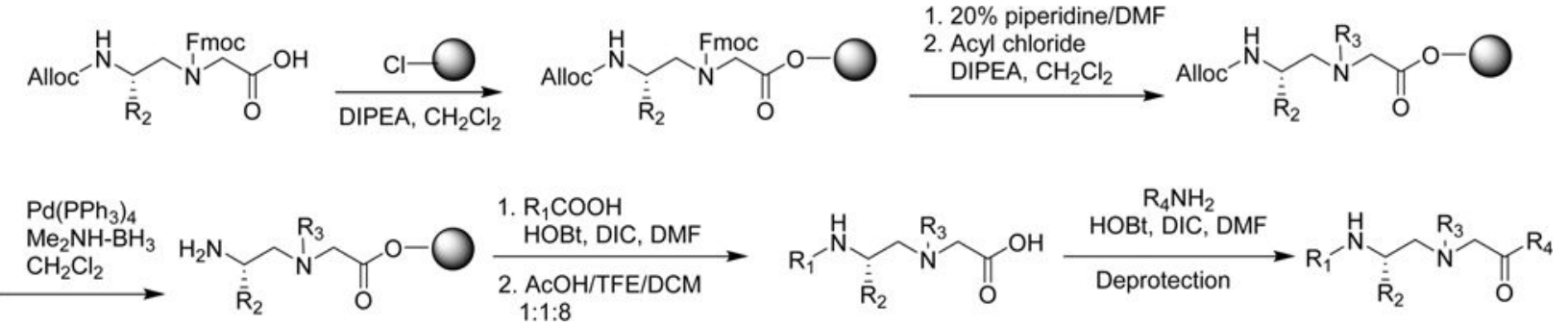

Figure 3.

General scheme for the preparation of small reduced dipeptide derivatives. 


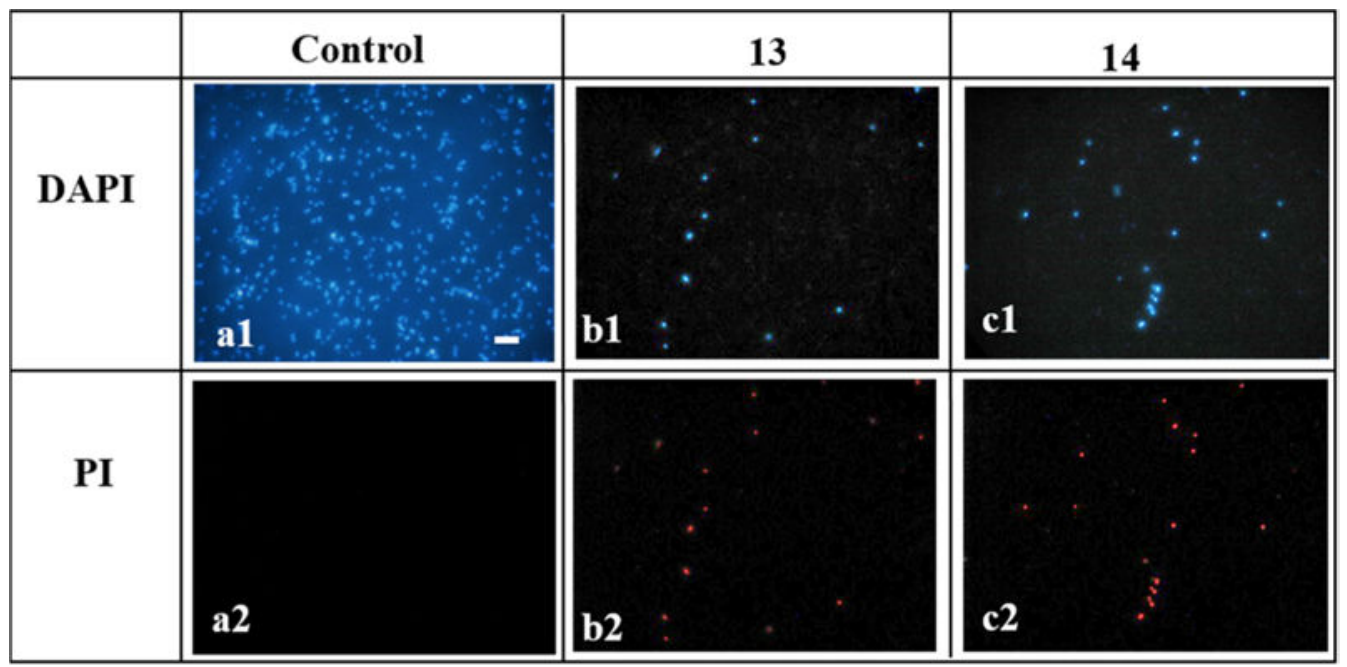

Figure 4.

Fluorescence micrographs of $S$. aureus that are treated or not treated with $25 \mu \mathrm{g} / \mathrm{mL}$ of 13 or 14 for 2 h: (a1) control, no treatment, DAPI stained; (a2) control, no treatment, PI stained; (b1) treatment with 13, DAPI stained; (b2) treatment with 13, PI stained; (c1) treatment with 14, DAPI stained; (c2) treatment with 14, PI stained. Scale bar $=10 \mu \mathrm{m}$. 

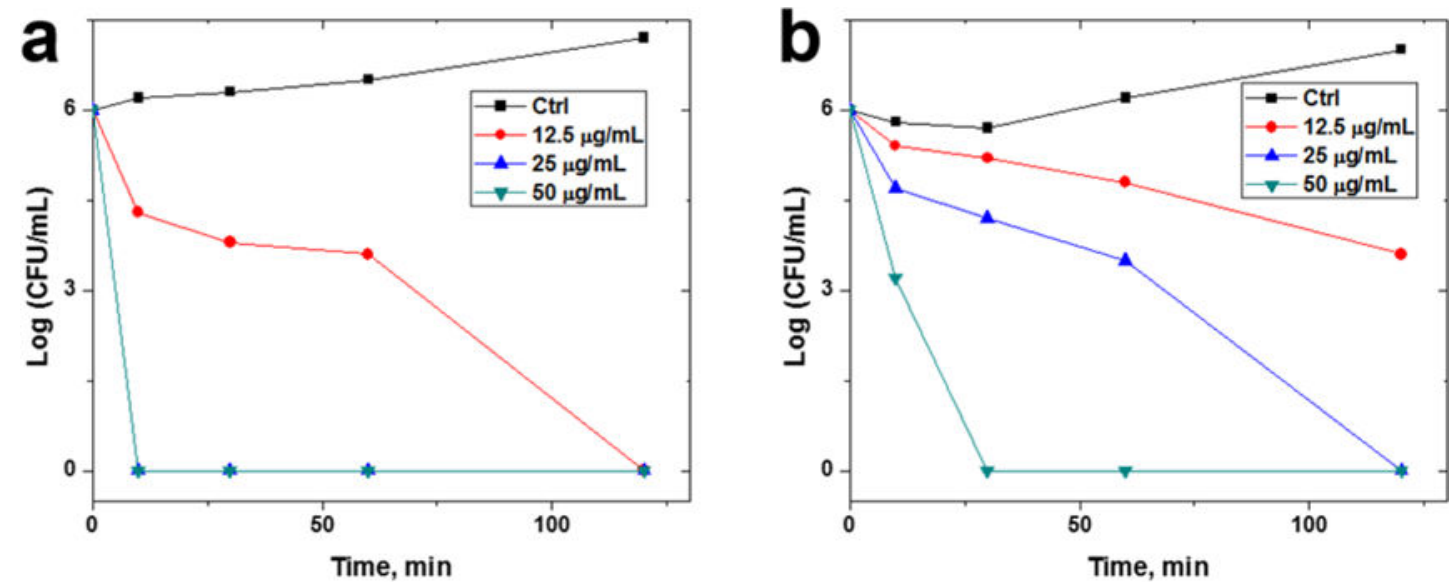

Figure 5.

Time-kill curves of $\mathbf{1 3}$ (a) and $\mathbf{1 4}$ (b) for $M R S A$. The killing activity was monitored for the first $2 \mathrm{~h}$. The concentrations were $4 \times$ MIC, $8 \times$ MIC, and $16 \times$ MIC, respectively. 


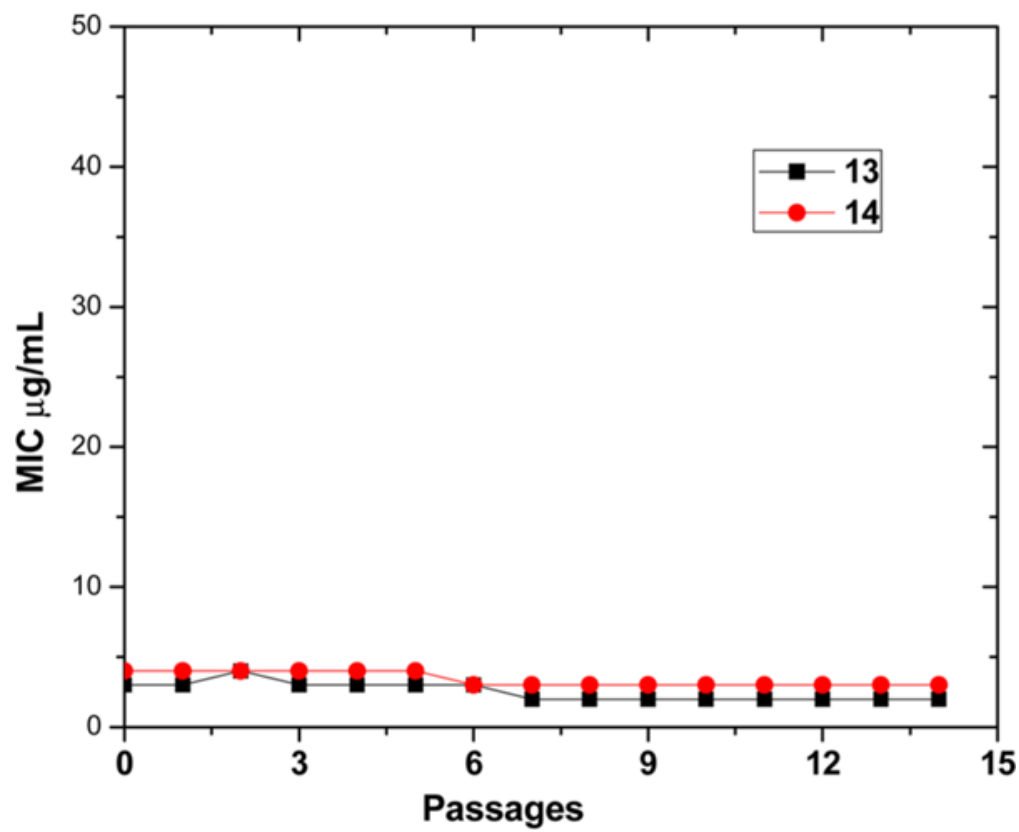

Figure 6.

Drug-resistance study of $\mathbf{1 3}$ and $\mathbf{1 4}$ toward MRSA. 


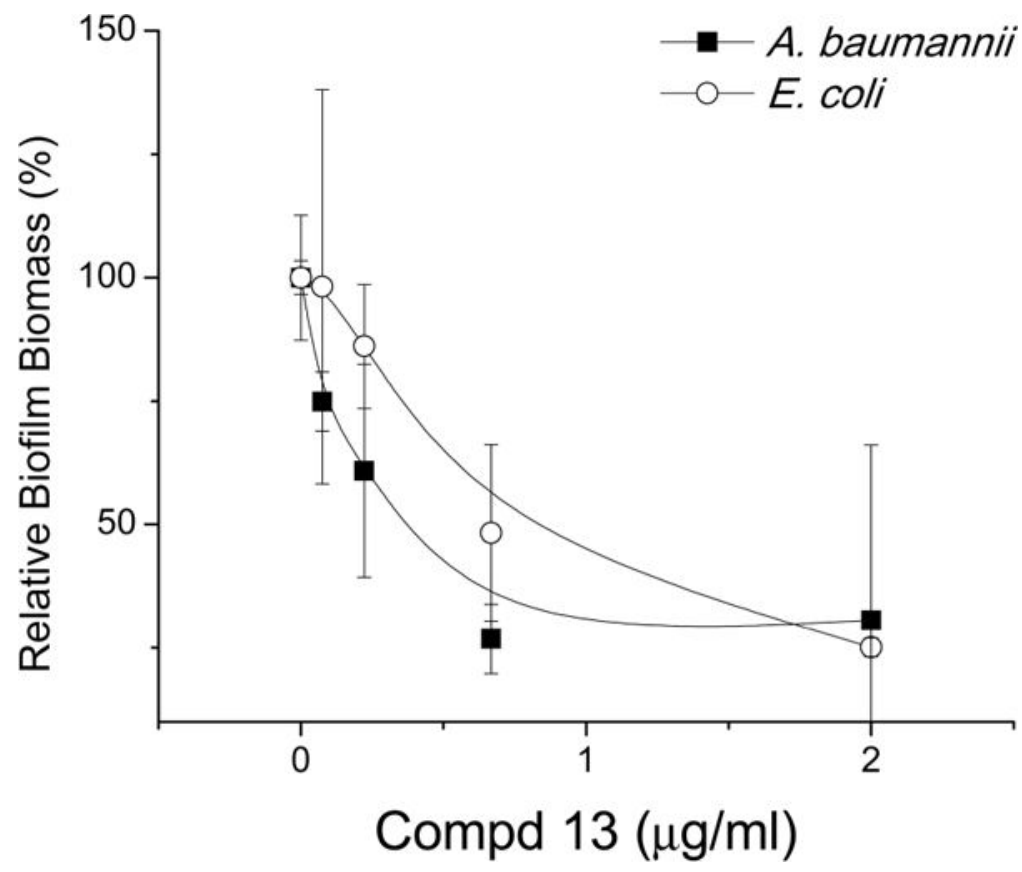

Figure 7.

Biological activity of compound $\mathbf{1 3}$ on inhibition of biofilm by $A$. baumannii and $E$. coli. 
a

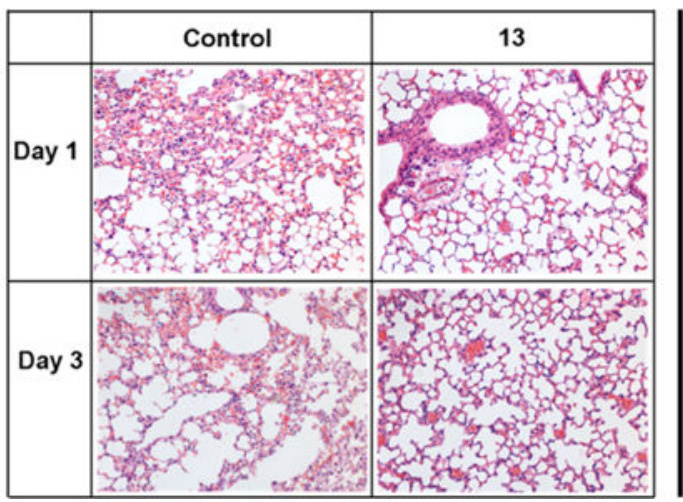

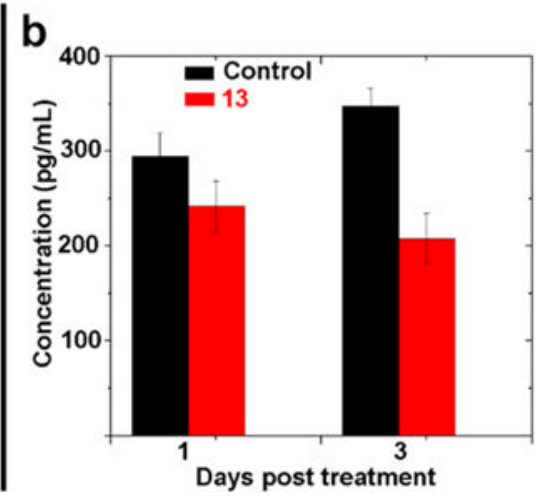

Figure 8.

In vivo efficacy of compound $\mathbf{1 3}$ on a MRSA-induced ventilator-associated pneumonia bearing rat model: (a) pathological assay via H\&E staining; (b) TNF- $a$ cytokine level in the rats by ELISA assay. 


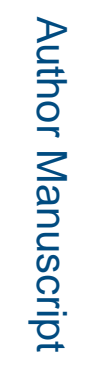

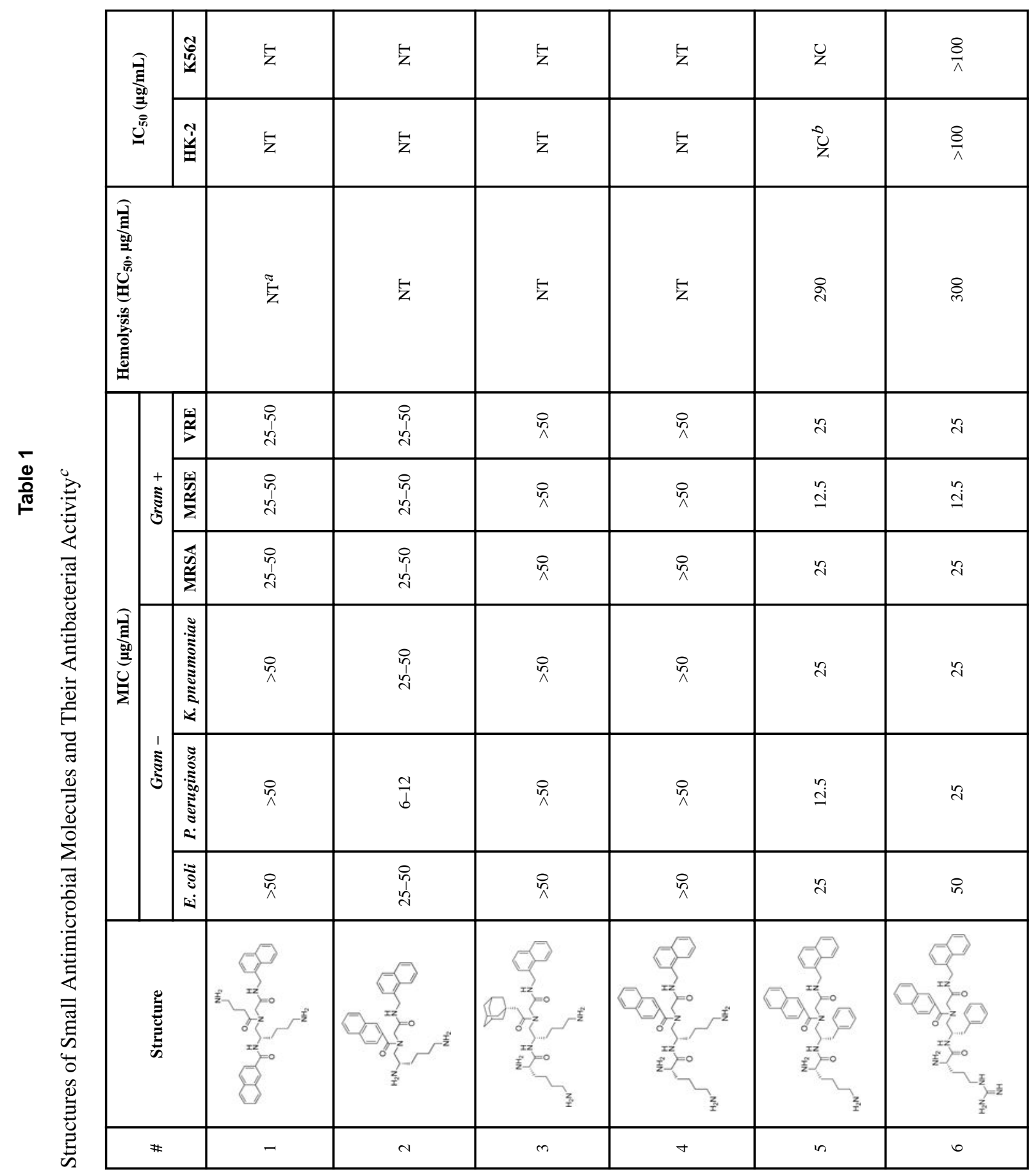

JMed Chem. Author manuscript; available in PMC 2017 March 10. 


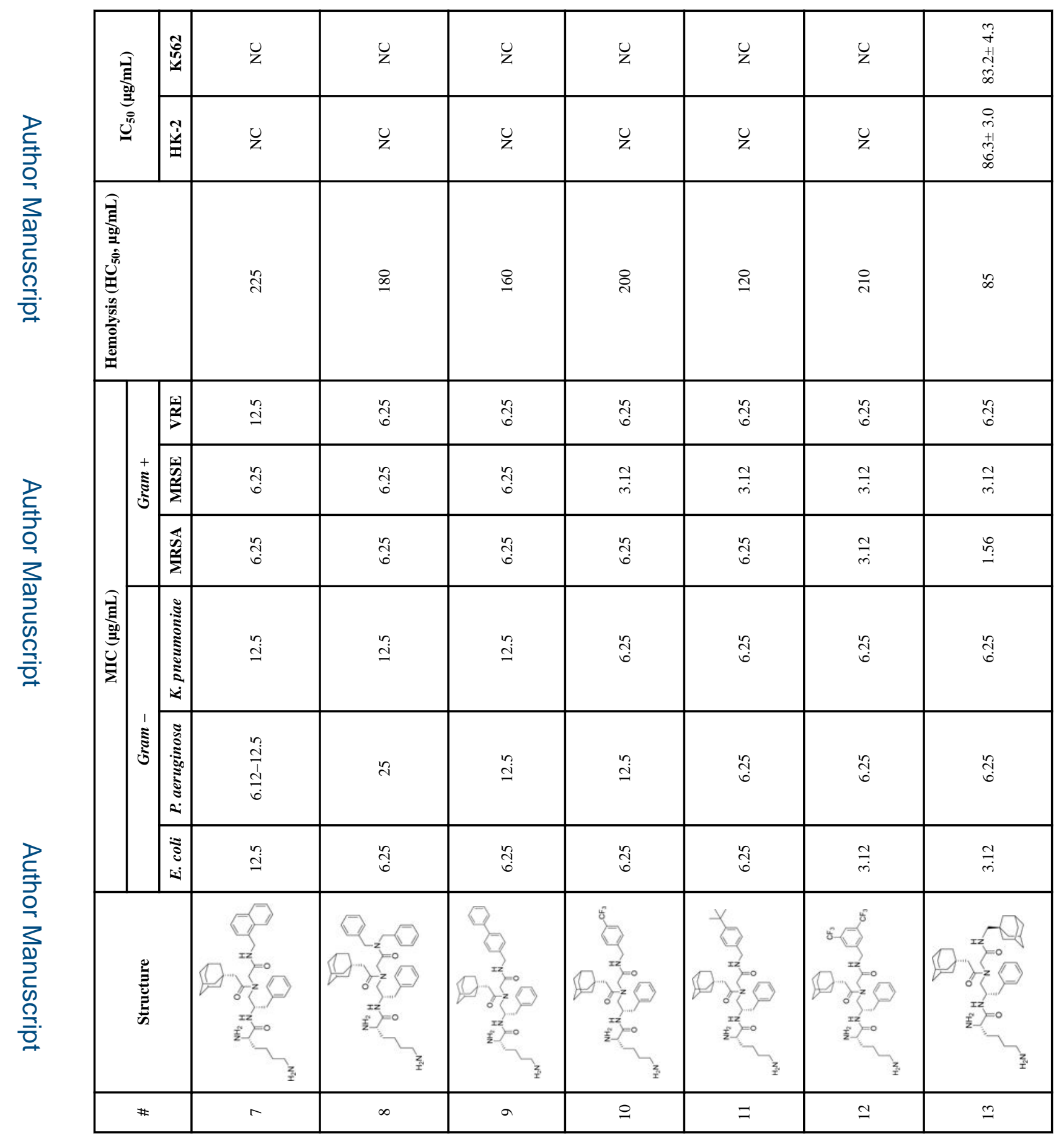

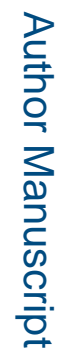




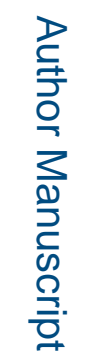

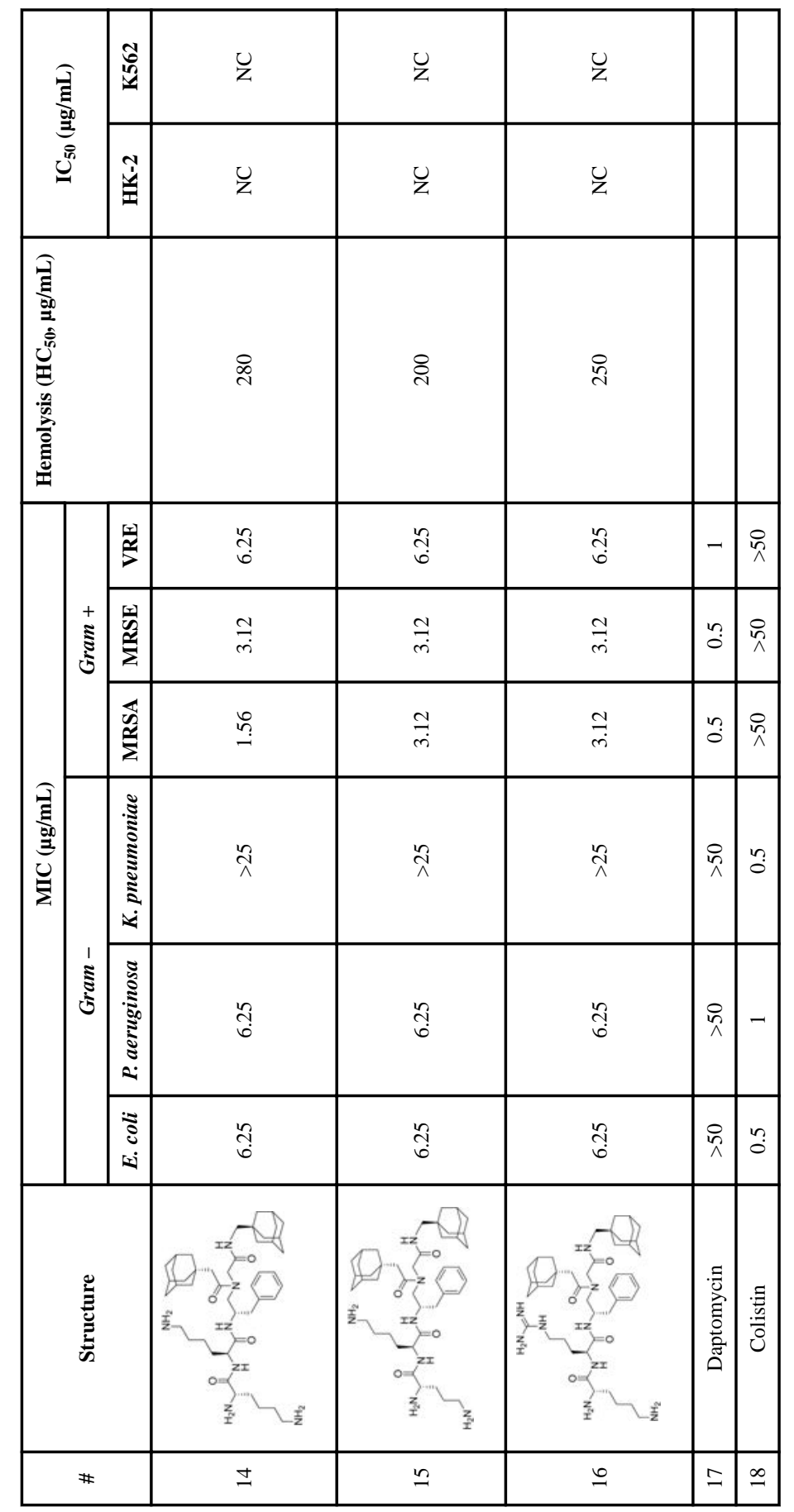

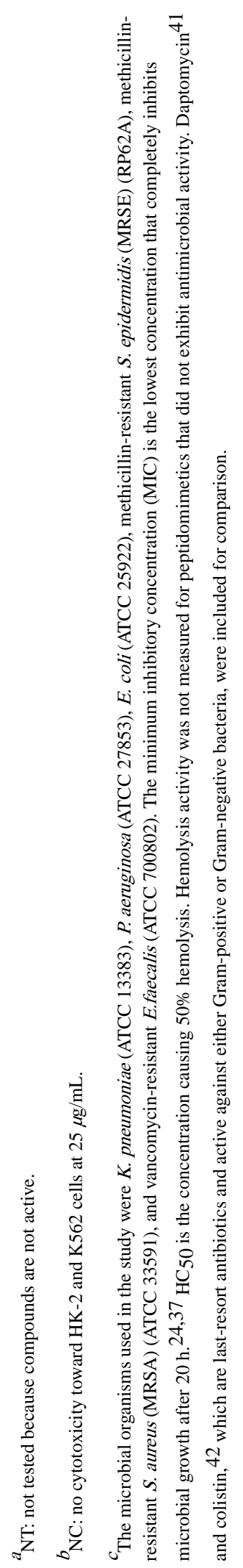

JMed Chem. Author manuscript; available in PMC 2017 March 10. 